Ministry of Education and Science of Ukraine Simon Kuznets Kharkiv National University of Economics

\author{
A. A. Kud, M. A. Mashchenko, \\ I. S. Pypenko, I. V. Soboleva
}

\title{
PREDICTING \\ THE IMPACT OF DIGITAL ASSETS \\ ON SOCIOECONOMIC DEVELOPMENT \\ OF AN ENTERPRISE
}

Methodical Manual

Kharkiv

"KRPOCH"

2020 
UDC 338.12.017(072)

DOI 10.26697/9786177089116.2020

P 91

\author{
Recommended by the Academic Council \\ of the Faculty of Economy and Law of S. Kuznets KhNUE \\ (Protocol No. 6 dated March 11, 2020)
}

Authors:

Kud A. A. (Section 2), Mashchenko M. A. (Introduction, Section 3, Conclusions), Pypenko I. S. (Section 1), Soboleva I. V. (Section 3).

\title{
Reviewers:
}

Gavkalova N. L. - Doctor of Economic Sciences, Professor, Head of the Department of Public Administration and Regional Economics of Simon Kuznets Kharkiv National University of Economics.

Marchenko O. S. - Doctor of Economic Sciences, Professor, Professor of the Department of Economic Theory of Yaroslav Mudryi National Law University.

Kud, A. A., Mashchenko, M. A., Pypenko, I. S., \& Soboleva, I. V.

$P 91$ (2020). Predicting the Impact of Digital Assets on Socioeconomic

Development of an Enterprise [Methodical Manual]. Kharkiv: KRPOCH. doi:10.26697/9786177089116.2020

In the methodical manual the phenomenon of socioeconomic development has been studied, the peculiarities of the sociocultural context, which form the understanding of the essence of socioeconomic development, have been substantiated; the influence of modern information technologies, which significantly change the models and ways of doing business, has been determined. On the basis of etymological analysis the essence of the concept "digital asset" and the essence of predicting socioeconomic development from the influence of digital assets in the conditions of economy antimonopolization have been studied. The principles of building economy antimonopoly regulation in the conditions of the economy digitalization have been determined. This study is agreed and approved as the research paper of S. Kuznets KhNUE (Agreement No. 649-56 dated December 13, 2019).

The methodical manual is addressed for specialists in the fields of information and digital economy, lawyers, financial organizations and representatives of business communities.

UDC 338.12.017(072)

The publication is placed in international repositories and databases: Crossref, Google Scholar, Scilit, eKRPOCH, Kopernio, etc.

ISBN 978-617-7089-11-6
(C) S. Kuznets KhNUE, 2020

(C) Kud A. A., Mashchenko M. A., Pypenko I. S., Soboleva I. V., 2020

(C) KRPOCH, 2020 


\section{CONTENTS}

List of Abbreviations and Symbols $\quad 4$

Introduction

Section 1. Theoretical Basis of Socioeconomic 6

Development in the Current Context

Section 2. A Complex of Basic Concepts of the "Digital 23

Asset" Phenomenon

Section 3. The Impact of Digital Assets on

Socioeconomic Development and the Role of Predicting in the Context of Economy Antimonopolization

Conclusions

References 


\section{List of Abbreviations and Symbols}

ED - Engineering Developments

EU - European Union

GDP - Gross Domestic Product

IMF - International Monetary Fund

ILO - International Labor Organization

IT - Information Technology

R\&D - Research and Development

UNDP - United Nations Development Programme

USA - the United States of America 


\section{INTRODUCTION}

Improvement of the living standards depends on socioeconomic development of a state. At the current stage, the world socioeconomic development is increasingly influenced by digitalization processes, which change approaches to solving problems at different levels and in different spheres of life. They are mainly aimed at finding new opportunities to improve welfare and address pressing social issues starting with those of healthcare, education and environment. Digital technologies, which have emerged over the last decade, help us to find sources of efficiency and opportunities for rapid competitive development of market business structures. The development of digital economy in general and digital technologies in particular has led to the emergence of a "digital asset" and the rapid development of related processes.

As the problems of socioeconomic development of national economy intensify, the question of finding an effective model of public economic management in Ukraine, one of the key functions of which is predicting, arises. Such issues are also relevant in view of the growing problems of monopolization of national markets, closing up of small and medium businesses. The priority direction of the antimonopoly regulation system development is to change the general concept of such regulation and to introduce the European model of antimonopoly policy. However, it is safe to say that it is necessary to clarify the theoretical foundations of the antimonopoly system and build its structure taking into account the predicting function in a digital economy.

The aim of this research is to develop a theoretical and methodological basis, methodological approaches and practical recommendations for predicting the impact of digital asset on socioeconomic development of an enterprise. 


\section{SECTION 1. THEORETICAL BASIS OF SOCIOECONOMIC DEVELOPMENT IN THE CURRENT CONTEXT}

Understanding of socioeconomic development in economics has changed since the discipline emerged: from economic growth through economic development to socioeconomic development.

As the world economy changes so rapidly, the key drivers behind the global socioeconomic change include changes in production and consumption patterns, new technology innovations and ways of doing business, as well as social and political changes.

In the context of considering this phenomenon, it is important to explore the features of the sociocultural context that form its understanding, as well as the impact of modern information technology, which significantly changes the models and ways of doing business.

Technology is a key factor in these changes; new technologies have significantly improved the fields of production, finance, communications, etc., thereby the world is rapidly integrating into a single market. Trade and direct foreign investments, along with wider geographical spread of income and opportunities growth, contribute to further integration of an increasing number of countries into wider international exchange.

According to the latest data provided by the World Trade Organization, trade and globalization in general have brought enormous benefits to many countries and people. Trade has allowed countries to benefit from specialization and economies to produce on a more efficient scale. This has increased productivity and income, stimulated economic growth, facilitated spread of knowledge and new technologies, and expanded the range of choices available to consumers.

Global trade, flows of goods and services are crucial to achieving sustainable growth in developing countries. Increasing capital flowing across national borders makes a significant contribution to economic growth and poverty reduction along with trade. International mobility and division of labor also lead to significant changes in the distribution by countries.

Many governments of developing countries have recently opened their economies to international trade through a multilateral trading system, enhanced regional cooperation, or programs of domestic socioeconomic development reforms. 
Despite the recent global economic crisis, the world trade has risen sharply over the past decade, almost tripled. Developed countries are still major players in the international trade, while the share of developing countries is growing. The integration of developing countries into the world economy, despite good results in general, was quite different. East Asia continues to dominate the trade flows of developing countries, while other regions lag far behind. China becomes an increasingly important trading partner for many other developing countries, not only in the East Asian region, but also in sub-Saharan Africa and Latin America.

According to the official statistics of the Ministry for Development of Economy, Trade and Agriculture of Ukraine, we can study the dynamics of economic development in Ukraine over the past year [1].

By indicators of increase/decrease:

- industrial production: 0.0\% (January-September, 2019);

- agricultural production: +5.9\% (January-September, 2019);

- capital investment: $+12.3 \%$ (January-June, 2019);

- direct foreign investment: $+2.6 \%$ (as of July 1, 2019);

- foreign trade in goods (balance): -5842.7 million U.S. dollars (January-August, 2019);

- foreign trade in goods (export): +6.9\% (January-August, 2019);

- labor market (according to the ILO methodology): 8.5\% (JanuaryJune, 2019);

- labor market (wages): +9.5\% (January-September, 2019);

- consumer prices (until December of the previous year): $+3.4 \%$ (September 2019 to December 2018);

- consumer prices (until the previous month): $+0.7 \%$ (September 2019 to August 2019).

Thus, the analysis of economic development in Ukraine provided by the Ministry is an important but limited means of studying the socioeconomic development of a state, as it does not reflect sociocultural context, priorities set by international institutions, etc.

Our research opens new opportunities for systematic analysis of this complex process in the EU over the past decade and on this basis we can predict trends in Ukraine's economy, taking into account the views of international institutions, the impact of society and market relations, and modern digital technologies in general. 
Let us consider the phenomenon of socioeconomic development in detail.

Today, the sources of the best definition of socioeconomic development and a factor influencing the way this phenomenon is understood are mainly the documents of international agencies (e.g. development agencies, the United Nations Development Programme (UNDP), the Food and Agriculture Organization of the United Nations (FAO), the International Monetary Fund (IMF), the World Bank) and declarations of countries cooperating to achieve the goals of this development. For example, the development goals framed in the Millennium Declaration proposed by UNDP in 2000 include poverty reduction, health care, sustainable use of resources, education, food security, and efficient management. Considerations on development are no longer perceived in the context of poverty reduction in lagging regions. Such a broad understanding of socioeconomic development plays an important role. This change is due to the growing importance of humanism, as well as philosophical and sociological ideas about equality of opportunity. Obviously, the popularity of caring for the environment and awareness of the role of social capital are also important factors.

Economic growth, which is a "constant and natural economic right", is manifested in an increase in total production, which leads to improved living standards. Economic theory gives three reasons for economic growth: capital accumulation, population growth and technological progress. Today's discussion on the determinants of growth points to additional issues, such as investment in productive capital, investment in human capital, R\&D, openness to trade and access to developed financial markets. This is complemented with appropriate economic policy that keeps inflation at the desired, stable level and legal and institutional conditions that create a business-friendly environment that encourages business start-ups.

Unbalanced distribution of growth factors has a negative impact on the local, national and regional economies. This situation affects unbalanced economic development, which means multifaceted social development. Disparities in socioeconomic development, in turn, negatively affect the efficient use of available economic resources and are recognized as a major barrier to economic development. 
The question of how to reduce disparities in socioeconomic development is the subject of research and practical measurement of the European Union concept. The transformation of the European Community into the European Union, an economic and monetary union, has led to measures to reduce inequality in economic development between its members. According to the Treaty on European Union "in all its activities, the Union shall aim to eliminate inequalities (...)" [2]. This should be done through a cohesion policy, the scope of which (spatial and temporal) has developed over the years. Previously, the cohesion policy focused on plans and funding within national policies; over time, the investment horizon and spatial scale have been expanded from domestic investment to crossborder or regional investment (EU macroregions) [3]. Achieving the goal of the Treaty on European Union required greater financial commitment to the regions with weaker economic conditions. They included mainly the countries of Central and Eastern Europe, which joined the EU in 2004, 2007 and 2013. Despite that at first the reduction in inequality was limited primarily to reducing the gap between GDP per capita and unemployment rates, changes in the EU development priorities have led to a change in perception. As a result, it was more important which inequalities needed to be reduced. The economic indicators (GDP, unemployment rate) were justified in assessing the implementation of the Lisbon Strategy, which envisaged that Europe would become the most economically competitive region by 2010. The unsuccessful implementation of this strategy has led to a change in the priorities of EU Policy. The new priorities are described in the Europe 2020 strategy, which envisages that by the end of the second decade of the 21 st century, Europe will be more coherent than ever and its development will be "... reasonable by means of more efficient investment in education, research and innovation; sustainable, due to strong progress towards a low-carbon economy; and inclusive, with a strong emphasis on creating jobs and reducing poverty" [4]. Taking into account the above development priorities, there is a need to extend the set of indicators to five areas: (I) employment, (II) research, (III) climate change and energy, (IV) education; (V) combating poverty and social exclusion, the size of which is the basis for assessing progress towards the goals. In the document "GDP and beyond. Measuring progress in a changing world" [5], besides complementing the environmental and social indicators, the European Commission also proposed [5, p. 5-11]: 
1) real-time information for decision making;

2) more accurate reporting on distribution and inequalities;

3) design of a European sustainable development board;

4) extension of national accounts to environmental and social issues.

The modified approach to measuring inequalities between regions has also changed the scope of cohesion policy issues. In the financial perspective for 2014-2020, besides unemployment, industry and agriculture, much attention was paid to differences in "... innovation, level of education, environment and poverty" [3, p. 200]. Efficient use of available resources and connection of economies with transport systems and information technology are necessary for growth acceleration. The financial instrument of the EU (Connecting Europe Facility (CEF)) is the answer to these questions, the main aim of which is to support the economic growth, increase the employment rate and the competitiveness of the EU economy by financing cooperative infrastructure investment in the EU. The CEF-funded projects are "...filling the gaps in European energy, transport and digital base" [6].

The economies of Central and Eastern Europe, which were the last to join the European Union (last three expansions of the EU: 2004, 2007, 2013), differed from the economies of previous EU member states. This was a consequence of the political and economic division of Europe into two regions after the World War II. In economic terms, these are the spheres of market economy and centralized planned economy. The political and economic transformations that began in the late 1980s allowed some countries to join the European Union. The EU members (from this region of Europe) were: Estonia, Latvia, Lithuania, Poland, the Czech Republic, Slovakia, Slovenia and Hungary in 2004, Bulgaria and Romania in 2007, and Croatia in 2013. The differences between the socalled old and new EU members were manifested in all aspects of the state functioning, which are governance, economic, social, legal, financial, etc. The weaknesses of the post-socialist economy were inefficient and unprofitable economic structures, strong ties with the Soviet economy (the largest, sometimes the only exporter of resources and importer of finished products), delays in the development of key industries, namely transport, energy and communications, compared to Western Europe. In 2014, a joint report "Completing Europe - From the North-South Corridor to Energy, 
Transportation, and Telecommunications Union" [7] was prepared by the Central and Eastern Europe Energy Partners (CEEP) in collaboration with the CEED Institute with the support of the LOTOS S. A. Group and the Oil Exploitation Enterprise S. A. PERN "Friendship". The report presents the opportunity to "complete the integration" of the European Union by creating a network of energy, transport and communication links in Central and Eastern Europe. In the report, in addition to the so-called new members of the European Union, Austria was also included in the suggested North-South infrastructure corridor due to its strategic location.

The initiative for close cooperation between the former socialist countries was first suggested by the President of Croatia. The meeting in New York on the occasion of the UN session in autumn 2015 was the beginning of joining efforts to strengthen the countries of Central and Eastern Europe. The name "The Three Seas Initiative" was proposed as a reference to the region to be covered - the European states between the Baltic, Adriatic and Black Seas. Despite the fact that the countries invited to the Initiative make up almost $43 \%$ of all EU members, they make up less than $30 \%$ of the EU surface area and their population is just a little over $20 \%$ of the EU population.

This means that the members of the Initiative are small countries, both in terms of area and population. As a result, the lack of economies of scale means that some investments in transport, energy and transportation are not profitable. However, without these investments, the progress will not be as rapid as in Western Europe (except Austria).

The goal of the Initiative is to equalize the levels of economic development that require action to increase cohesion, complementarity and, ultimately, prosperity. Energy, transport and digital communications have been identified as key areas of cooperation.

The Modified Social and Economic Development Index (SEDI) is used to assess the level of development. The index allows for a multidimensional analysis of socioeconomic development and the position of the studied economy in relation to selected economies.

The indices included measures related to various socioeconomic aspects. Their choice was closely connected with the priorities set out in the Europe 2020 strategy. The study examined the differences between countries that have undergone political and economic transformation and the so-called old members of the Union. As the study concerned the 
countries participating in the Three Seas Initiative, Austria was also analyzed, along with the post-socialist countries. The SEDIs were calculated for all twelve countries of the Initiative and for the whole European Union. The SEDIs were calculated for 2004, 2009 and 2013.

2004 is the year when the European Union expanded the most, and its structures began to operate in eight countries of Central and Eastern Europe. Thus, the SEDIs showed the position of these countries in contrast to Austria and the EU as a whole. Although the next expansion took place in 2007, another SEDIs were only calculated in 2009. It was the fifth full year when eight countries were operating in the EU and the third year of membership of Bulgaria and Romania. In addition, in 2009, the economy suffered most of the effects of the financial crisis, and this was reflected in annual figures. 2013 was chosen as the year of the last EU expansion to Croatia.

Based on the results, it is concluded that post-socialist states have not only joined the EU with much weaker economies, but also are unable to effectively reduce their socioeconomic gaps, despite operating within the EU. In 2004, the highest indices were achieved for the economy of the entire European Union followed by Austria. In 2004, only Slovenia and Estonia reached levels above the SEDI average. All other countries had lower SEDIs. In 2004, the most prominent economies were those of Croatia, Bulgaria and Romania, which were not yet members of the EU in the year under study. In 2009, the "new" countries of the European Union had lower SEDI averages with the exception of Slovenia. This was a consequence of the financial crisis, which was particularly felt by the weakest economies. In the case of Austria, Slovenia or the European Union as a whole, the average increased, which means that despite difficult economic environment, there had been socioeconomic growth. Economically weak countries have been seriously affected by the economic recession manifested itself in very high unemployment rates, reduced investments and lower $\mathrm{R} \& \mathrm{D}$ investments. The largest decreases were recorded in Bulgaria (by 32\%), Poland (by 25\%) and Lithuania, Latvia, Hungary (by 22\%). The Gini index was used to find out if inequalities between the countries increased in 2004-2009. It was identified that the difference in SEDIs in 2004 generated the Gini index at $\mathrm{IG}_{2004}=0.100069$, the Gini index in 2009 increased to $\mathrm{IG}_{2009}=$ 0.196556 [8]. 
The significant differences in the level of socioeconomic development that emerged in 2009 were not compensated for over the next few years. Despite the fact that the SEDI of the European Union decreased a little (9\% compared to 2009) and all the assessed economies grew, this does not mean equal development. In 2013, the Austrian economy and the average level of economic development of the EU were significantly different from those of the rest of the countries and there was also a growing disparity among the economies that had undergone transformation. If in 2004 only two "new" countries had their SEDIs above the EU average, in 2013 only four countries exceeded this average (Slovenia, the Czech Republic, Estonia and Latvia), and two more (Slovakia and Poland) had their SEDIs a little lower than the average. At the other end of the rating, the SEDIs were the same as those of Croatia, Romania and Bulgaria. Throughout the study period, half of the economies increased their potential for decisive socioeconomic development, taking into account the growth rates of SEDIs. These were the economies of Austria (68\%), the EU (26\%), Latvia and the Czech Republic (13\%), Slovenia (9\%) and Slovakia (5,2\%). Lack of progress towards the goals of the Europe 2020 strategy with decreasing SEDIs was recorded in Bulgaria $(-26 \%)$, Croatia $(-12 \%)$, Estonia $(-6 \%)$, Lithuania and Romania $(-5 \%)$, Hungary $(-4 \%)$ and Poland $(-1 \%)$. Despite the fact that different courses of changes were observed in the surveyed economies, the range of which was high (from $68 \%$ of SEDI growth to $26 \%$ in SEDI), SEDI changes in the Initiative region slightly decreased compared with 2009 , though they were still higher than in 2004. The Gini index was $\mathrm{IG}_{2013}=0.16$.

Thus, the countries that have joined the Initiative retain a huge difference in the socioeconomic development measured by SEDI. Austria remains a decisive leader in its development. Among the countries that have undergone systemic transformations, the socioeconomic conditions in Slovenia and the Czech Republic have changed the most rapidly. The worst situation was in the Balkan countries, namely Bulgaria, Romania and Croatia. On the one hand, the weak position of the three countries with the lowest SEDIs may be due to the shortest period of membership in the European Union. On the other hand, it may also mean that it is impossible to overcome the weaknesses that have to a certain extent affected all economies under the influence of the Soviet Union. This is confirmed by Gini index, which shows that during the global recession, the "new" EU 
states significantly suffered from the crisis. The diversification of economic development deepened considerably. The global economic recovery helped some economies (Slovenia, the Czech Republic, Estonia, Latvia, Slovakia and Poland), but for Bulgaria or Romania the changes were almost imperceptible. This situation was reflected in a slight change in the Gini index from 0.19 (in 2009) to 0.16 (in 2013).

Thus, the analysis shows that the Three Seas Initiative states do not have adequate capacity to ensure faster and better growth of these economies, which is the goal of the Europe 2020 strategy.

Let us consider the phenomena of socioeconomic development in the context of the market economy, in particular in terms of the impact of entities and organizational units of the public sector on the processes of socioeconomic development.

In a market economy, socioeconomic development is considered as the result of interaction of organizational structures and units of the public sector, the role of which is to support and stimulate development, especially among private sector organizations responsible for the actual course of economic processes related to market production and services. Therefore, studying the relationship between organizations, organizational units that are part of the public sector, and enterprises operating in the real market conditions, leads to the establishment of the cause-and-effect relationship, as well as to the determination of the role and importance of specific groups of subjects and their impact on the economic processes in market conditions. The principles and methods of providing social services play a distinctive role here. In the context of this research, social services include all administrative measures related to the social needs of people, medical services, education, personal social services, care services, housing services, employment services and specialized services, as well as remittances for different groups of society.

In the current unstable conditions of economic markets, as well as increasingly unstable market mechanisms in Europe and the world, it is necessary to examine both the opportunities of and threats to supporting socioeconomic processes in a market economy. It is important to pay attention to the significantly diverse range of tasks and responsibilities of organizational structures and units that are part of the public sector and enterprises operating in the real field of market conditions. It should be emphasized that investment expenditures are the most important factor 
that directly affects the level and quality of public services, including the level and quality of social services.

However, the broader context of development processes, including the role of the public sector and social services, cannot be ignored, especially with regard to global development issues, as generally defined in the concept of the development economy. According to the concept of the development economy, the optimal allocation of resources should be sought and economic growth of poor countries that do not always participate in the globalization and development should be supported.

Therefore, the next task of the research is to identify and analyze the current opportunities and obstacles that arise in the process of financial development at the regional and local levels, in the market economy of EU countries.

The main focus of this research is limited to determining the role of organizational structures and units of the public sector in supporting economic development and providing social services.

In a market economy, economic and social phenomena can be studied both from the macroeconomic and local points of view. A similar pattern applies to the form of the above relations between public and private sector actors. A significant amount of public sector influence on the economy is used at the state level by the government administration, including both functions of establishing regulations at the executive level and a number of measures at the level of public intervention with a strong financial component, as well as by control functions. Particular attention should be paid to direct financial activities carried out through investment financed from the state budget or a system of project-oriented subsidies intended for various sectors of the economy and used to support certain social and economic goals, and especially to support processes related to the provision of social services.

Despite the undoubtedly important role of state support provided at the central level, the current trends of socioeconomic change indicate the need for a careful analysis of development issues from a local point of view. The essence of the regional approach to economic and social processes is to identify the development potential of the region, external conditions that form the region's position in the business environment, as well as to determine competencies and relations between entities that have access to various economic resources of this region and formation of 
opportunities and forms of their application. In view of this, it is worth noting the special role of public sector actors at the regional, local levels.

In this structure, the local self-government of the region performs important functions in relation to the administrative territory, which is subordinated to the above-mentioned government. These are, in particular, the functions that coordinate a number of development-oriented activities carried out by local self-government bodies of districts. In terms of shaping future social and economic phenomena at the local and regional levels, some attention should be paid to strategic management tools, long-term investment programs, long-term financial management of tangible assets owned by local governments, as the main area of making decisions the consequences of which lead to improvement of the quality of life of residents of this administrative unit.

The scope of competencies, as well as the area of responsibility of local self-government can refer to many areas of administrative and service activities, as well as investment activities, which largely determine the effectiveness of short- and long-term establishment of development conditions. Therefore, an important task of local government is to analyze and make decisions on the implementation of investment proposed by social groups (councils, social organizations, etc.), as well as taking into account the initiatives and proposals submitted by potential external investors.

With regard to investment made directly by local governments, it is necessary to properly assess the rationality of such projects, which can be demonstrated by the preparation of each investment project in terms of its scale, referring to factors such as the number of future users and features specific to technical and social infrastructure elements. One of the most important factors may be the massiveness of infrastructure elements, which often determines the lack of substantiation for implementing investment projects of small material and, consequently, financial scale, and imposing large complex projects with high financial expenditures as a consequence.

The role of local governments in the context of the formation of development phenomena is manifested in the implementation of intentions, comprehensively describing all areas of operation and the special nature of this unit, while maintaining the scope of competencies that are adequate for the public sector. The modern conditions of market 
economy considerably force to achieve a certain level of economic efficiency of actions carried out by local communities. In addition, along with civilizational progress, social expectations are growing, including both stricter environmental requirements and the need to introduce new technologies, which creates the need to provide more funds for the construction, maintenance and modernization of infrastructure components. The desire to increase the degree of social satisfaction in a market economy in relation to the public sector requires developing new management concepts, including management based on analogies between departments that provide public services, and management of the organization focused on profit.

In the EU, as in any other highly developed countries, changing ways of approaching the issue of managing entities and organizational units in the public sector, including local governments, moves towards greater efficiency and effective functioning, as well as towards the provision of social services. Important changes in the formation of development processes are related to the increased independence of local governments and promoting, at least tentatively, the attitude of the "manager", which encourages greater activity and responsibility for tasks, including the need for new, more effective strategic planning solutions and predicting the consequences of actions for the future.

This problem is of a broader social and economic nature, as it extends beyond states and regions. This is manifested in a number of problems in various forms of organization and functioning of the state and society, in many demographic problems and in many problems in the provision of public services. There are many examples where these problems have led to a number of dangerous tense situations in the world. One possible solution is to refer to the concept of development economics.

As for the local self-government units, an important problem is the function of the system of pooling resources and financing various state tasks. In this aspect, it is a problem of both decisions on the total amount of public funds and decisions on their detailed use. This is also related to the issues of financial independence of local self-government, and hence the level of independence of individual units of the central government. To a large extent, the independence and financial stability of local selfgovernment, and thus the ability to ensure the proper process of providing public services and the possibility of a long-term approach to development 
of a particular administrative unit, are determined by the structure of budget incomes. At the same time, it should be emphasized that the basis of financial savings of local governments is the budget, which is a decentralized plan of income and expenditures.

The above considerations point to the critical problem of the systematic formation of local government income sources, including the search for the optimal ratio of incomes, called own and external income, including, in this case, transfers from the state budget and subsidies from public funds. The high level of own income, taking into account at the same time its stability, can be considered as one of the vital factors of financial independence of local self-government. At the same time, this does not diminish the importance of external income, as despite the fact that it undoubtedly limits the financial independence, this income is an important element of regional policy acting as a support in selected areas and at the same time controlling certain areas of financial economy of local self-government through state institutions of public administration. Analyzing the problem of independence, we should determine the sphere of freedom that local self-government units actually have, not only in terms of pooling budget funds, but also in terms of spending them. The greater the extent of such independence of local governments, the more autonomous the actors involved in the development process are.

Assuming a simplified approach to the issue of financial independence based on the characteristics of the above category of income, it can be stated that independence in terms of income can be achieved only when the dominant role in financing local governments is played by income itself. As for the independence of expenditures, it will grow with the increase in the share of own income and total subventions in the structure of incomes of local governments. Under this approach, it would be much easier to ensure independence in terms of expenditures, as both own income and total subvention are distributed on the basis of decisions made by local legislatures and executive bodies.

The analysis of the actual degree of financial independence of local self-government is a rather difficult task, taking into account the ambiguous assessment of the criteria for these problems. However, it is possible to use the analysis of certain indices, including the index of estimation of the share of own income of local self-government units in the total income of the government sector or the index of the share of own 
income of local self-government units in its total income. Increase in these indices means the financial independence of local self-government has improved.

Deteriorating economic conditions and declining incomes in the real sector lead to restrictions on current activities, reduced expenditures (often due to lower employment) and limited investment, as well as an increase in the share of decisions on partial or complete termination of business. From the public sector point of view, the above-mentioned phenomena lead to a significant risk of reducing the amount of taxes paid to the state budget, shares of which from are transferred to the budgets of local governments. The characteristic tendency of modern public funding systems for the budget income "to depend on the amount of public fees" increases the sensitivity of the public sector, both to changes in the real economy and to cross-relations. The example of the economic situation in some developed countries compared to the economic slowdown in many EU countries in the post-2008 period indicates the leading role of public sector actors in shaping the development of the financial crisis and attracting existing sources of public expenditures. Lack of public sector activity will further deteriorate the institutional infrastructure, weaken the regulatory functions of public administration and reduce the quality of public services, including social services, which will result in worsening of governance conditions for the private sector.

In the course of the analysis, assumptions were made about the equivalence of development conditions and investments. Investment expenditures can be considered equivalent to development. This follows from the statement that investments support economic potential allowing it to increase its scale both quantitatively and qualitatively, as well as using public services, including social ones. With regard to local selfgovernment units, the principle of development is enshrined in strategic planning documents, including projects related to quantitative and qualitative changes in future.

Funding for local government is still strongly linked to the need to catch up with the development of infrastructure, both economic and social. Despite the favorable situation regarding the ability to generate funds allocated for investment projects, more attention should be paid to the use of external capital in financing investment expenditures, as well as the growth of public debt, as they are factors indicating the structural 
mismatch between budget incomes and needs of social services of local communities determined under new conditions.

An important challenge in the decision-making on the investment projects initiated by local governments is the rationality of spending public funds. Therefore, at the stage of preparation of development plans or investment programs, it is necessary to improve the methods of analysis of the economic efficiency of specific investment projects, as well as the impact of a particular project on the functioning of the local economy. Services of general interest and social services are usually characterized by low price flexibility and demand income, which means that both changes in prices and income have little effect on changes in demand and, consequently, on the level of demand. The phenomenon of low flexibility of demand in this area of services has a specific impact on the whole process of providing services. In addition, some public services, especially social ones, are provided free of charge, which means that their effectiveness cannot be assessed only with financial tools. Similarly, investment made to increase the fixed assets of provided services should, to a greater extent, be valued using instruments that measure not only the financial effects but also the impact on the environment and social effects that form the future attractiveness of the territorial unit as a place of residence and development of local entrepreneurship.

Taking into account the expected limitations on the availability of non-repayable foreign investment capital, there is an important element in the budget economy of a particular local government unit that is to maintain a budget balance and a secure level of debt. Due to the insufficient level of sociotechnical infrastructure, which still exists in many local governments, and the phenomenon associated with this insufficiency, namely the expectation of faster satisfaction of collective social needs, many units turn capital-absorbing investments into tangible assets. Excessively high debts and related long-term debts can significantly block or reduce a unit's ability to create new investment projects. These problems occur quite often. In the transition period, it is possible to restore the structures of the state and society and put socioeconomic processes on the track of development. Numerous difficulties in the functioning of the state and the provision of services in the public sector still exist in poor countries. In a broader context, in many poor countries, development dilemmas still await effective solutions. 
As mentioned above, in a market economy, socioeconomic development is the result of entrepreneurial tasks implemented in organizations operating in the open market. Thus, we can conclude that the need for interaction of public and private sector actors follows from the fact that local governments are only responsible for a small range of tasks, including mostly public ones.

At this stage, it is worth noting the importance of dynamically growing groups of participants in development processes at the local level, namely the cooperation of local governments with non-governmental organizations in the provision of services and social investments. Organizations that are considered as part of the sector of unprofitable organizations and at the same time constitute objects of the social economy can be considered as an important and still developing group of participants in socioeconomic processes in the EU, and as a group of participants that gradually solves a large part of social problems, which traditionally the state dealt with.

The results of the analysis let us suggest that the role of private and public sector entities in the processes of socioeconomic development is undoubtedly significant. Units of local governments are still responsible for the formation of development phenomena. However, this role remains limited, while the focus of economic effects has shifted to the real and the private sectors. The financial independence of local governments has been weakened as local governments have become significantly dependent on both external and repayable funding. In particular, repayable funding intended to achieve investment objectives is long-term. Decisions made in such cases may have long-term consequences that exceed the current term of office of the local governments involved in decision-making. Despite the existing guarantees of decision-making continuity in public administration, it is worth emphasizing the importance of direct responsibility for any potential consequences of the actions taken, which may adversely affect the budget situation in the future. According to the analysis, the responsibility for development decisions and their future economic and social results are one of the most important and, at the same time, the most difficult elements of public sector participation in the economy at the local level and in the process of forming and stimulating its development. Among many problems that remain unsolved, we need to mention the proper assessment of the needs of social services, the 
improvement of investment project preparation processes, including all relevant tools for planning and assessing the material and financial volume of projects, and the responsibility of local governments' investment projects, comprehensively describing all areas of operation of this unit. Taking into account all past experience related to the functioning of local governments in the EU, it should be noted that these entities are responsible for a significant area of public services, including social services, which often involve investment. Due to this, there are serious limitations, which are the discrepancy between the scope of activities and that of tasks. The result of this discrepancy is the search for local government units for extra-budgetary sources, including mainly repayable sources. However, this may be a constraint on future funding opportunities for development. The organization of social services is still a complex process. These services are characterized by high demand for investment capital and high operating expenditures. An important feature of social services is that they are free of charge, which means that all expenditures associated with their provision are funded by government agencies, and citizens use services for free.

The rapid development of new platforms and technologies has accelerated the development and growth of the financial services sector, which has attracted more attention from regulators and policymakers in various jurisdictions. The development of financial technology is revolutionizing the way people interact with financial services around the world. These innovations are characterized by faster payments, securer transactions, reduced remittance expenditures and financial access in areas where traditional financial instruments cannot be used.

Digitalization becomes part of everything today, and entities are no exception. Many entities in the world (especially in North America) have digital education, and therefore have high annual profitability, and its benefits are reflected in the country's GDP and employment levels.

Ukraine is just at the beginning of this path, as it has a very low level of investment in R\&D and does not have a complete digital transformation due to inactivity of employees and financial hostility of management, as digital transformation is considered a very expensive step and does not provide immediate benefits in the near future.

It should be noted that European funds play a major role in financing investment in digital transformation and innovation. 


\section{SECTION 2. A COMPLEX OF BASIC CONCEPTS OF THE "DIGITAL ASSET" PHENOMENON}

The current stage of the economic development of society is characterized by the formation of a new field of economy - digital economy, which is caused by the increasing role of digital technologies as well as information and communication technologies in the development of all major sectors of science. Digital technologies that have emerged over the past decade help to find sources of increased efficiency and the possibility of rapid competitive development of market business structures. At the same time, they require restructuring of existing business processes based on new values, priorities and focus on customers, innovation, uniqueness, right to use and transfer, synergy.

The development of the digital economy as a whole, and of digital technologies in particular, has led to the emergence of a new term "digital asset" and to the rapid development of related processes.

Today, the term "digital asset" does not have a single comprehensive definition that would fully reveal the essence and content of the term. This fact greatly complicates the understanding of many processes related to the use of digital assets and quite often affects the distortion and misinterpretation of information laid down in the basis of existence of digital assets. Such terminological confusion creates stable conditions for further establishment of the inconsistency and ambiguity not only of the term "digital asset" itself, but also of the prospects for its use. Therefore, it is relevant to clarify the definition of the term "digital asset".

The analysis of modern scientific publications and research works on digital assets shows that today there is no clear definition and understanding of this term.

Thus, one group of scholars [9-18] employs the term "digital asset"; the second group [19-21] employs the term "cryptocurrency"; the third group [22] employs the term "token"; the fourth group [23] employs the term "virtual asset"; the fifth group of scholars [24-26] employs several terms simultaneously as synonyms, i.e. close intertwining of terms can be observed.

When developing the terminological apparatus, we have referred to the recommendations of GOST 3966-2000 [27]. 
To substantiate the essence and content of the term "digital asset" in the economic and legal aspects, the following complex of theoretical research methods has been used: deduction and induction, analysis and synthesis, comparison, generalization, systematization and interpretation of results.

The clarification of the term "digital asset" should be based on a clear terminological definition of "digit" (derivative "digital") and "asset".

Initially, the word "digital" was used to describe information expressed in numbers. Data, such as images, sounds, words, are represented as a set of digits ( 1 and 0 ) in the binary system, which is used directly in the computer field [28]. In the Explanatory Dictionary, the term "digital" is considered as the one translating information using electronic systems into a binary code intended for the sequential processing, storage and transmission of the corresponding information. These definitions confirm that the term "digital" is closely related to the processes of dissemination and integration of information and information technologies into various fields of activity, and is an integral part of the terms and processes that characterize changes occurring not only in the financial and economic sector, but also in society as a whole.

The essence and content of the term "asset" should also be considered. In the Explanatory Dictionary of Finance, the term "asset" is interpreted as a subject of objective reality, be it tangible or intangible, which has some value to the holder of assets [30]. In the Encyclopedic Dictionary [31], the component parts of a property are determined as an asset, excluding existing debts, i.e. commodities, cash, securities, promissory notes, machines, tools, land and buildings, etc. In turn, in the Modern Economic Dictionary, one of the definitions of the term "assets" is clarified as the total amount of money and property that belongs to a business entity (firm, enterprise, company), which the funds of their owners were previously invested in [32].

When considering the term "digital", it was revealed that it includes both numerical combinations and coding of various types and methods as well as the technology of converting anything into an electronic format (digitization). Most sources link the term "asset" with tangible or intangible resources and property rights. It represents a kind of value, whose owner can be one person as well as an enterprise or society as a whole. By combining these two terms, a digital asset can be defined as a 
value expressed in a digital form. Therefore, a digital asset is a set of digital (binary) data that are autonomous, uniquely identifiable and have a certain value.

The use of the term "digital asset" in its modern understanding is first and foremost caused by the emergence of the Blockchain technology and cryptocurrencies. In 2009, the first cryptocurrency Bitcoin was created, which became a new phenomenon in the field of economics. Simultaneously, the Blockchain technology was developed, which is a distributed ledger that is a sequential chain of transaction blocks built according to certain rules, where each subsequent block contains information about the previous one. Such a Blockchain operation allowed ensuring safety and transparency of transactions and processes conducted in it, which is the reason why this technology found its application in many fields. Such tendencies have contributed to the rapid development of the digital economy and attracted a lot of interest from society towards the phenomenon of digital assets. However, due to an ambiguous interpretation and the absence of basic criteria of the definition, some things are called "digital asset", when in reality they are not one.

Therefore, when clarifying the definition of the term "digital asset", we will adhere to certain essential semantic features represented by the following four components: 1) economic; 2) legal; 3) information; 4) value.

Let us consider them in more detail on the basis of the following research methods: deduction and induction, analysis and synthesis, comparison, generalization, systematization and interpretation of results.

1. Economic component in the context of the definition of the term "digital asset". This component's significance in the financial field is represented by a unique identifier.

In order to substantiate appropriateness of using the component "in the form of a unique identifier" in the term "digital asset", let us consider the definitions separately. According to the Explanatory Dictionaries [29; 33], the word "unique" means single, rare, exclusive, exceptional, or one that exists in a single copy. The word "unique" originates from the Latin "unicum" and means "one and only". Of the variety of interpretations of "unique", it is necessary to take the meaning "one-of-a-kind" as a basis in order to properly understand this term in the definition of a digital asset. 
In the age of information technology and the development of computer technologies, the term "identifier" is strongly associated with the information environment. For example, Email, phone number or code can be used as a network identifier.

The meaning of the word "identifier" in the Great Explanatory Dictionary of Modern Ukrainian Language [34] is as follows: identifier is the name of the program object (variable, array, structure, function, etc.), which allows referring to the object; an attribute that generally defines an entity in a predetermined space. The identifier is always: a) unique considered as an indivisible (atomic) lexeme; b) identical - indicates only one entity; c) valid in only one address space.

The essential characteristic of an identifier is reflected in the tasks of programming languages in determining applicability of local changes [34]. In the Concise Dictionary of Cybernetics, an identifier is presented as a conventional name (label, word) of a collection of information or a group of data, which allows finding and, consequently, retrieving such information from the memory [35].

To clarify the procedure for submitting documents to the state register and to regulate the circulation of electronic documents of legal entities and natural persons, the term "unique identifier" is used. It means a logical sequence of characters using which the applicant, on the official website of the special authorized body on state registration issues, provides information on the status of electronic documents submitted by him/her in order to register a legal entity or a natural person (entrepreneur), as well as receives electronic documents sent to him/her by the state registrar [36]. The term "unique identifier" is also used in the field of electronic auctions and refers to a set of numbers and letters, which the auction platform automatically assigns to any distributed bandwidth that was distributed between users according to the results of the electronic auction [37].

The unique identifier is used in information systems and is intended to identify a specific object in the network, as well as allows excluding any probability of duplication of this object and confirms its authenticity.

Based on the interpretations of the terms "unique", "identifier" and the word combination "unique identifier", we can conclude that the component "in the form of a unique identifier" indicates the form of representation of a digital asset and implies that it has a unique name. The alphanumeric code assigned by the system, in which the digital asset 
circulates, allows distinguishing a specific digital asset in the distributed ledger and obtaining the necessary information about it.

With the emergence of the distributed ledger technology, whose structure guarantees safe information storage and the possibility of asset verification, the digital asset obtained a unique property. Any changes made to the distributed ledger (Blockchain) automatically lead to the generation of a new unique identifier, which eliminates the possibility of duplication and illegal use of the asset. The information about a digital asset contains the following characteristics: its location, registration, legal restrictions and other distinctive features and properties. The Blockchain provides the conditions for identifying a digital asset by giving it a unique hash code, which allows assigning such an asset to a specific entity.

2. Legal component in the context of the definition of the term "digital asset". This component is represented in the legal field by a derivative of the right.

For the correct interpretation of the component "derivative of the right", it is necessary to define "derivative" and "right". First of all, let us consider the dictionary materials. Thus, according to the Explanatory Dictionary [29], derivative should be understood as derived from another object or formed from another object. In the Explanatory Dictionary [33], derivative is suggested to be understood as something that is obtained from something else, or something derived.

Now, we consider it appropriate to analyze the term "right". It should be mentioned that the polyparadigmatic approach to the understanding of right is caused by the origins of this phenomenon and the centuries - old philosophical polemic around it and, as a result, the ambiguity of its interpretation. Moreover, this word has multiple meanings and is used in everyday speech to refer to various phenomena. In the Explanatory Dictionary of the Russian language [38], the following three interpretations of the term "right" are proposed: a) formalized set of rules of behaviour; b) science, which studies the corresponding formalized rules of behaviour; c) measure of possible behaviour, freedom of action provided by the state.

It should be mentioned that it is the third way of interpretation of right in the definition of Ushakov D. [38] that is closest to the true understanding of the definition in the context of the term "digital asset". The language structure "right to" will be used in the author's definition of 
the term "digital asset". In this case, "right" can be replaced with the "guaranteed possibility of something", wherein the original meaning will be preserved.

The division of the right into its objective and subjective understanding was employed in the Large Legal Dictionary [39] as well:

a) objective meaning of right - a combination of official rules of law that are established and enforced by the state (positive right); rules that derive from the nature of law, which is above formal law (natural right);

b) subjective meaning of right - a measure of the possible behaviour of an entity (rights).

Thus, it is the subjective meaning of the interpretation of right in this source that refers to the definition of the term "digital asset" under consideration. In terms of legal doctrine, Matuzov N. and Mal'ko A. [40] define right as a normalized, orderly form of manifestation of freedom, which is guided in a legitimate direction.

Having analyzed different meanings of the word "derivative", we can conclude the following: all these terms have a certain basic phenomenon, the subject (source), which determines the origin of a derivative. In other words, "derivative" emerges as a result of the transformation of the source (basic phenomenon) and is able to retain basic properties or rely on them. In turn, the properties of derivatives are predetermined by the properties of sources.

Based on the above-mentioned definitions of right, it can be concluded that in the definition of the term "digital asset", the subjective approach to interpreting right as the type and measure of a person's possible behaviour that are governed by legal norms will be used.

According to the analysis of the definitions of the component "derivative of the right", we can state that they most fully reflect the essence of the principle laid down in the definition of the term "digital asset". A digital asset is not the right to a value in its interpretation, but it has attributes of a derivative of the right to a value.

3. Information component in the context of the definition of the term "digital asset". This component is represented in the IT field by an information resource circulating in the distributed ledger.

So far, the component "information resource" does not have a universal comprehensive definition. The interpretation of this term varies 
depending on the subject areas and approaches, in the context of which it is considered.

The term "information resource" is defined in legislative acts as:

a) a combination of documents in information systems: libraries, archives, data banks, etc. [41];

b) an organized combination of documented information, including databases, other combinations of related information in information systems [42].

The term "information resources", formed in Encyclopedia of Modern Ukraine [43], defines these resources as information, which is presented in a specific form, stored, accumulated, processed and used by interested parties in an appropriate manner. Information resources are characterized by an emergent property, as an information resource can contribute to the formation of new knowledge. Information resources can be interpreted by both a human and a computer program. Dolinko V. [44] states that an information resource is data in any form, which are characterized by the possibility of their multiple use. In the Financial Dictionary [45], information resources are defined as a set of data that are systematized for the subsequent effective acquisition of the necessary information.

Poljakov and Kosarev [46] point out, that in the twentieth century, the value of information is increasing like never before. Therefore, this led to the emergence of such a fixed expression as "information resources" at one of the UNESCO congresses. According to the authors, information resources are a product of intellectual activity. Poljakov V. and Kosarev V. [46] state that a special characteristic of information resources is that they do not disappear after a certain period of time. In turn, Shuremov E. [47] defines information resources as knowledge recorded on a tangible medium, which can later be used by interested parties. At the same time, we should consider the point of view of Prokopenko A. [48], who says that an information resource is not just any information, but only the information that is properly arranged and structured. As for Bachilo I. [49], she notes that an information resource is only the information that has practical significance, which gives it social relevance.

From all the above-mentioned definitions and clarifications of this term, we can conclude that an information resource is information structured and organized in a certain way and recorded on a tangible 
medium. Information can be stored, transmitted, used, and updated. An information resource has the properties of practical significance and usefulness as well as the possibility of multiple use ("inexhaustibility"). Unlike other types of resources (natural, economic, temporary), the quantity and quality of information resources increase as they are used. Such a cumulative effect along with the development of modern technologies contributes to the rapid increase in the information potential of society as a whole.

Thus, a digital asset is an information resource in the sense that the information on a value presented in a digital form has such main properties of an information resource as: a) information is structured according to certain parameters and categories; b) information is recorded on a digital medium; c) information can be stored, transmitted, exchanged, used, etc.

In addition, a digital asset in our understanding has an additional property - information on a value is formed by the owner of this value. It should also be noted that an information resource in the context of the definition of the term "digital asset" is deprived of such a characteristic as the possibility of being copied an unlimited number of times. This is due to the fact that in the distributed ledger, each such resource is expressed in the form of a unique identifier, which ensures stable conditions for the guaranteed ownership of a digital asset by a specific entity. Thus, the following important conclusion can be reached: the value of a digital asset lies in its uniqueness and credibility, which are ensured by circulation of the digital asset in the distributed ledger. Based on these characteristics, one can also designate the high practical significance of the digital asset in the economic and legal aspects.

The component "circulating in the distributed ledger" in the context of the definition of the term "digital asset".

Let us consider the notion "circulating" on the basis of various sources of information. Thus, in the Financial and Investment Explanatory Dictionary [50], the term "circulating" is used in the context of monetary or financial values that are to be transferred or sold to another entity. Taking into account that this concept is most often used with nouns, its meaning can be most fully revealed in the context. Thus, in the Financial Dictionary [51], the definition of "negotiable instruments" (which can be classified as circulating) is given, which means financial instruments and securities, which can be the object of free civil (economic) turnover (for 
example, promissory notes, bonds, checks, warrants). In addition, it should be taken into account the synonyms to this term for a broader understanding of its meaning: circulating means transferrable, rotating, transitory.

It is also necessary to consider the semantic content of such a category as "distributed ledger". The term "distributed ledger" has many definitions. Thus, according to the data of the US Federal Reserve System, the distributed ledger is a type of database that is distributed between network nodes; a specific combination of components, including, but not limited to, peer-to-peer networking, distributed information storage and cryptography, which can potentially change the way a digital asset is stored, recorded and traded [24].

According to Walport, UK Government Chief Scientific Adviser, a distributed ledger is essentially an asset database that can be shared across a network of multiple sites, geographies or institutions. It should also be noted that all participants within a network can have their own identical copy of the ledger. Any changes to the ledger are reflected in all copies in minutes. The assets can be legal, financial, electronic or physical. The security and accuracy of the assets stored in the ledger are maintained cryptographically [52]. This new technology of a distributed information storage is called Blockchain. This technology allows, among other things, keeping records of transactions with both tangible and intangible assets. The Blockchain technology allows digitization of information and its safe transmission. The advantages of this technology are as follows: stability; security; transparency [53, p. 3-4].

Savel'ev A. [54] defines "decentralized data ledger" as an information system that includes a distributed database and contains information on concrete facts and (or) data on the property right, which is confirmed by certain algorithms.

One of the key properties of a digital asset is the ability to circulate in the digital environment, rather than being copied during transmission from one email address (storage, wallet, cell) to another. A circulating object (digital asset) should necessarily have not only its own circulation environment, but also clearly defined rules and conditions for its existence in such an environment. To be able to establish and monitor the implementation of such rules and conditions, a reliable digital scalable and decentralized ecosystem is needed, which will allow all participants to be 
confident that the uniqueness of information resources will be preserved. That is why the component "distributed ledger" occupies an important place in the definition of a digital asset.

The distributed data storage system of such ledgers is one of the most technologically advanced. It provides the highest possible level of confidence in the information due to the mandatory procedure of verifying it for accuracy by all nodes of the distributed environment through a certain method of building consensus. Thus, the problem of "doublespending" is also solved. The information contained in such a ledger cannot be deleted or modified, and the reliability and mechanism of this storage method allow creating records on the right to values (assets) in the ledger. This is a necessary procedure in the process of creating a digital asset, which, in turn, requires recording information about the assessment (audit) and other data of the owner of the digitized value in the ledger, including his/her property right to a value. To understand the nature of a digital asset, it is important to take into account the mandatory conditions: the possibility of confirming that a digital asset belongs to a particular entity, as well as the absence of any means of creating a copy of the same digital asset, including by duplicating its unique identifier. Such conditions can only be provided by the distributed ledger technology, which allows guaranteeing the uniqueness of digital asset identifiers and assigning specific identifiers to specific objects.

Thus, it can be concluded that the ability to circulate in the distributed ledger for a digital asset is one of the determining ones. Therefore, the distributed ledger as an information storage system is the only possible environment for the existence and circulation of digital assets, which are, in essence, tokenized information resources derivative of real assets in the space of the distributed ledger.

4. Value component in the context of the definition of the term "digital asset". This component is represented in the field of tangible and intangible assets by the "value" component.

The term "value" has a number of definitions and interpretations that depend on the subject area of their application. In the Explanatory Dictionary [55], the term "value" is considered as the value of a particular object of tangible or intangible assets. There are two approaches to defining value. Thus, from the point of view of classical political economy (Classical school), value should be considered as an objective reality, 
which is measured by means of effort put into the production of certain goods. In turn, representatives of the neoclassical school directly associate the value with the rarity of the requested goods. The neoclassical approach is currently prevailing. In the Encyclopedic Dictionary [56], value is defined as either positive or negative significance of objects of the material or spiritual world for a person. The Explanatory Dictionary of the Russian language [38] has various definitions of value. Thus, according to the author, value should be understood as importance, significance and price of a particular phenomenon or object.

Taking into account the term involved, we can conclude that value is relative worth, utility, or importance, which can also be expressed by different measurement units depending on the area of practical use of such a value and the ecosystem in which such a value exists.

The phrase "derivative of the right to a value" will be used in the definition of the term "digital asset", since, in essence, digital asset is a kind of a guaranteed right to claim a certain value inherent in this digital asset. In other words, a digital asset serves as a tokenized information resource derivative of a value. Thus, it is the "value" component that should be used in the definition of "digital asset", since it conveys most widely and comprehensively the meaning laid down in the definition.

On the basis of the specified essential semantic characteristics, we will substantiate the term "digital asset" in the economic and legal aspects.

Digital asset is an information resource derivative of the right to a value and circulating in the distributed ledger in the form of a unique identifier.

The proposed term "digital asset" is represented by components (economic, legal, information, value), which are interconnected and interdependent.

Let us consider in more detail the terms used in modern scientific publications on the matter of a digital asset.

Today, a number of specialists define cryptocurrencies as a kind of digital assets. Thus, the leading crypto specialist of Cinnober fintech company, Wall [19], defines Ethereum as a digital asset. Tsegoev V. [21] applies a similar approach to the definition of Bitcoin. Garlinghouse, CEO of Ripple [20], also considers Bitcoin a digital asset, claiming that Bitcoin provides a user with the ability to solve specific real problems, which confirms that it has a value. 
There is also an approach whereby certain categories of tokens are considered digital assets. Velikaia E. [22] describes utility token as a digital asset that gives the holder of the relevant token the right to exchange it in the future for products or services that are directly provided by the issuer of the relevant token.

A separate group of experts likens digital assets to cryptocurrencies $[24 ; 26]$.

A specific approach is observed in the research work [25], where the author studied certain aspects of taxation of digital assets. Digital assets are objects that can circulate in the Blockchain systems. The scholar does not reduce digital assets exclusively to cryptocurrencies, as if deliberately leaving their list "open".

Social and economic foundation of the implementation of blockchain-based systems of digital assets in developing countries has been examined in the research work [16].

Some experts separate the terms "cryptocurrency" and "digital asset", indicating the fundamental difference between these terms [9-18].

Buntinx J. [12] says that a digital asset exists in a binary form, and any type of digital data can serve as a digital asset: from a film to a desktop folder. He considers the type of stored values to be the main difference between digital assets and cryptocurrencies. Most cryptocurrencies have a supply limit, whereas digital assets, if necessary, can be created (theoretically) an unlimited number of times.

A similar approach to the definition of the term "digital asset" was proposed by the researchers of groups of companies of the Centre for Innovative Technologies [9], who consider digital assets to be any events, facts, their characteristics and descriptions, which have been transformed into a digital form and, consequently, have a certain value. Thus, digital assets include such items as passwords, digital images, medical information, briefing notes, and any other elements that are mainly accessed through digital means such as books, music, and films. At the same time, from a legal point of view, digital assets can also be objects of intellectual property, namely, copyrights, trademarks, patents, etc. [17].

Harbinja E. [15, p. 102] and Walker M. [18, p. 53] consider any objects, which have a digitized form, to be a digital asset.

The definitions of a digital asset, which were formalized in legislative acts, are more comprehensive. The Fiduciary Access to Digital 
Assets and Digital Accounts Act [13] formalized the following definition of a digital asset: digital asset means data, text, emails, documents, audio, video, images, sounds, social networking content, codes, health care records, health insurance records, computer source codes, computer programs, software, software licenses, databases, or the like, including the usernames and passwords, created, generated, sent, communicated, shared, received, or stored by electronic means on a digital device.

New York's Fiduciary Access to Digital Assets Act [14] states that a digital asset means an electronic record in which an individual has a right or interest. This term does not include an underlying asset or liability unless the asset or liability is itself an electronic record. The given definitions were formalized in existing regulatory documents. Thus, we should also consider the definitions, which are enshrined in some draft laws. In the Draft Law of Ukraine No. 9083-1 [23], virtual assets are defined as tokens and cryptocurrency. This approach to the definition of a digital asset can be described as a narrow, crypto-oriented approach.

Sapozhkov O. and Kriuchkova E. [11] clarify that both rights from uncertificated securities and shares in the statutory capital of business entities can be certified by electronic data, i.e. "digital rights". In turn, the combination of relevant rights assigned to a specific person is already determined as a "digital financial asset".

Arianova T. [10] distinguishes three main types of a digital asset, which include: a) formal - fully centralized and can be referred to as those that transfer value only formally; b) cryptocurrencies - completely decentralized; c) hybrid -individual elements of the infrastructure of these assets are centralized, while others are decentralized or do not exist at all.

This indicates the resulting distinction in the use of this term in the field of information technology, and in the economic and legal fields. Despite the superficial similarity between the essence of a digital asset and the phenomena mentioned above, there are no uniform criteria that would fully describe its nature and properties.

Having analyzed the above-mentioned approaches regarding the term "digital asset", it can be stated that today there is a substitution of concepts in society, and a cryptocurrency is often called a digital asset. Such tendencies can be explained by a rather ambiguous cryptocurrency status and, therefore, attempts to minimize the negative attitude towards the phenomenon under consideration. 
Thus, scientific papers and research works on the interpretation of the term "digital asset" have been analyzed. The essence and content of the term "digital asset" have been analyzed on the basis of etymological analysis. The proposed term takes into account the essential semantic features of the phenomenon under consideration and is characterized by four components: economic, legal, information, value. This allowed substantiating the essence and content of the term "digital asset" in the economic and legal aspects, identifying features of the use of this term, as well as clarifying the interconnection and interdependence between its components. 


\section{SECTION 3. THE IMPACT OF DIGITAL ASSETS ON SOCIOECONOMIC DEVELOPMENT AND THE ROLE OF PREDICTING IN THE CONTEXT OF ECONOMY ANTIMONOPOLIZATION}

At the current stage, socioeconomic development of the world is increasingly influenced by the processes of digitalization, which are changing the approaches to solving problems at different levels and in different spheres of life. They are mainly aimed at finding new opportunities to improve welfare and address pressing social issues starting with those of health, education and environment.

As the problems of socioeconomic development of national economy intensify, the question of finding an effective model of public economic management in Ukraine, one of the key functions of which is predicting, arises. Such issues are also relevant in view of the growing problems of monopolization of national markets, closing up of small and medium businesses. The antimonopoly policy of the state, the functioning of its institutions and the system of economy antimonopoly regulation require a detailed study of the predicting function, its role and importance in shaping the antimonopoly policy of the state.

The main task in predicting the socioeconomic development of the economy is to determine the quantitative parameters and indicators for the development of the economic system in the future. There are two types of predictions:

- general economic predictions for the development of the economic system as a whole;

- predictions for the development of separate sectors and spheres of regional economy.

General economic predictions are the formulation of future development scenarios, which should be based on possible future situations.

Under the general economic prediction, it is necessary to define the most general indicators, which can be guidelines for further development.

These data can be an information basis for predicting the development of individual units of the regional system.

An important feature of predicting socioeconomic development is the need to predict regional development not only as an independent 
system, but also as part of the national economy. Long-term predictions are especially important in the management of the national economy and the development of regional socioeconomic systems. The increasing role of long-term predictions is the result of the conditions for the formation of a market economy. Inconsistency and, most importantly, the absence of these processes do not contribute to economic growth.

Predicting the socioeconomic development of the economy is not a new issue for the domestic scientific thought. Such scientists as Hrabovetskyi B. [57], Stelmashchuk A. [58], Shvaika L. [59], Dykan N. [60] and others dealt with solving problems of essence, methods and predicting tools.

However, despite the abovementioned, the issue of the role and importance of predicting in antimonopoly regulation of economic processes and predicting the impact of digital assets on socioeconomic development is insufficiently studied.

It is necessary to determine the essence, role and importance of predicting socioeconomic development for the national economy of Ukraine, especially in the antimonopoly sphere of the state.

The scientific works of foreign and domestic scientists are the theoretical basis of the study. To achieve this goal, the following research methods were used:

- system approach;

- method of analysis and synthesis;

- structural and logical analysis;

- methods of logical generalization.

Predicting occupies a special place in the system of public administration functions. State antimonopoly policy, its impact, the effect that is possible from the use of certain of its tools are the issues it deals with.

Predicting is a multidimensional phenomenon, it is at the intersection of sciences, so it is studied not only in economics but also in politics, sociology and other sciences. Predicting is always considered alongside and in connection with planning as inseparable and meaningfully interdependent state functions. This research emphasizes the importance of economic predicting of economy antimonopoly regulation under the conditions of the economy digitalization. 
In the system of state antimonopoly regulation, the predicting function also holds a prominent place. The priority direction of development of the antimonopoly regulation system is to change the general concept of such regulation and to introduce the European model of antimonopoly policy. However, it is safe to say that it is necessary to clarify the theoretical foundations of the antimonopoly system and build its structure taking into account the predicting function.

In our opinion, it is expedient to consider and study the essence of predicting. Scientist Hrabovetskyi B. [57, p. 6] understands predicting (from Greek - knowledge in advance) as a process of predicting based on the analysis of trends and patterns of the object (process) development.

Stelmashchuk A. considers predicting as scientific one substantiated by the system of establishing cause-and-effect relationships and patterns, identification of the state and probable ways of development of phenomena and processes [58].

Shvaika L. considers predicting as a certain set of ways and methods of thinking that are used on the basis of internal and external changes in the object of predicting to identify possible results of change [59].

In general, when studying the term "predicting" in economics, we can distinguish two approaches to its understanding.

1) Approach to the concept of predicting as a certain process (process approach) (Hrabovetskyi B., Stelmashchuk A., Koreieva E.);

2) System approach to the concept of predicting, understanding of predicting as a certain system of components (Shvaika L. and others).

Predicting the impact of digital assets on socioeconomic development under the conditions of antimonopoly market regulation will be further understood as the process of developing predictions on the basis of data on the object of regulation. Thus, the predicting of economy antimonopoly regulation in Ukraine in the context of the economy digitalization should be based on certain factual data, their study and interrelationship.

There are a large number of economic predicting methods in the scientific literature. When choosing a particular predicting method, it is necessary to understand the available methods and select the most relevant and reliable one. Thus, it is necessary to identify certain criteria of predicting methods' selection depending on specifics of the research object. 
We should also agree with the research [60] of scientists Dykan N. and Borysenko I., in which all methods of predicting are divided into three groups:

- informal, quantitative and qualitative methods. The first group includes all kinds of informal information which the subject of management obtains from outside;

- the second group includes calculation methods on the basis of which predictions based on internal information and statistical data are developed;

- according to the researchers, the third group of methods is used in cases where quantitative methods are too expensive or the obtained information is incomplete. On the whole, it is a method of expert assessments of specialists in a certain sector of the national economy.

The system of state economy antimonopoly regulation includes all state functions, which include predicting the antimonopoly activities of state bodies and the behavior of the monopolist, consumers and others.

The principles on which the system of the economy antimonopoly regulation is based are shown in Table 1.

Table 1. Principles of Building a System of Economy Antimonopoly Regulation.

\begin{tabular}{|c|l|}
\hline \multicolumn{1}{|c|}{ Principles } & \multicolumn{1}{c|}{ Characteristics } \\
\hline \multirow{2}{*}{$\begin{array}{l}\text { The principle } \\
\text { of consistency }\end{array}$} & $\begin{array}{l}\text { Provides that building and implementation of } \\
\text { antimonopoly regulation is considered not only } \\
\text { as an independent link, all elements of which are } \\
\text { interconnected and interdependent, but also as } \\
\text { part of all other areas of public administration; } \\
\text { focuses on a systematic analysis of the process } \\
\text { of antimonopoly regulation, clear defining of the } \\
\text { objectives and criteria of antimonopoly } \\
\text { activities; conducting structuring, which reveals } \\
\text { the whole range of issues that are subject to the } \\
\text { action of antimonopoly authorities. }\end{array}$ \\
\hline
\end{tabular}




\begin{tabular}{|l|l|}
\hline \multicolumn{1}{|c|}{ Principles } & \multicolumn{1}{|c|}{ Characteristics } \\
\hline $\begin{array}{l}\text { The principle } \\
\text { of purposefulness }\end{array}$ & $\begin{array}{l}\text { Lies in a clear and understandable formulation } \\
\text { of goals to ensure the effective outcome of } \\
\text { antimonopoly regulation. Defining the goal is } \\
\text { accompanied by coordination of the purposes of } \\
\text { all executors, taking into account real } \\
\text { conditions, regulatory documents, etc. }\end{array}$ \\
\hline \multirow{2}{*}{$\begin{array}{l}\text { The principle } \\
\text { of scientificity }\end{array}$} & $\begin{array}{l}\text { views to managing from a scientific point of } \\
\text { theoretical foundations of organizing activities, } \\
\text { management decision-making and its } \\
\text { implementation, awareness and analysis of the } \\
\text { results; taking into account the achievements of } \\
\text { antimonopoly regulation by management } \\
\text { entities. }\end{array}$ \\
\hline $\begin{array}{l}\text { The principle } \\
\text { of conceptuality }\end{array}$ & $\begin{array}{l}\text { Points out that the system of antimonopoly } \\
\text { regulation should be based on clearly defined } \\
\text { provisions, a system of views on this activity, } \\
\text { which will ensure the unity and logical } \\
\text { consistency of approaches in its organization } \\
\text { and evaluation. }\end{array}$ \\
\hline $\begin{array}{l}\text { The principle } \\
\text { of complexity }\end{array}$ & $\begin{array}{l}\text { Provides for the internal relationship of all types } \\
\text { of antimonopoly regulation and makes it } \\
\text { possible to eliminate the one-sidedness and } \\
\text { functionalism of the system of antimonopoly } \\
\text { regulation. }\end{array}$ \\
\hline
\end{tabular}

Thus, the above principles should become the basis of antimonopoly regulation, and are also fundamental in building a system of antimonopoly regulation in the context of the economy digitalization.

Predicting, like any economic process, is based on certain methods and has a certain organizational structure and stages. Step-by-step predicting schemes are proposed in the works of many scientists. In this case, in our opinion, predicting should be considered in the context of the continuity of its organizational and methodological support. The organizational and methodological support of predicting is proposed in Figure 1. 
Organizational and methodological principles of the predicting process
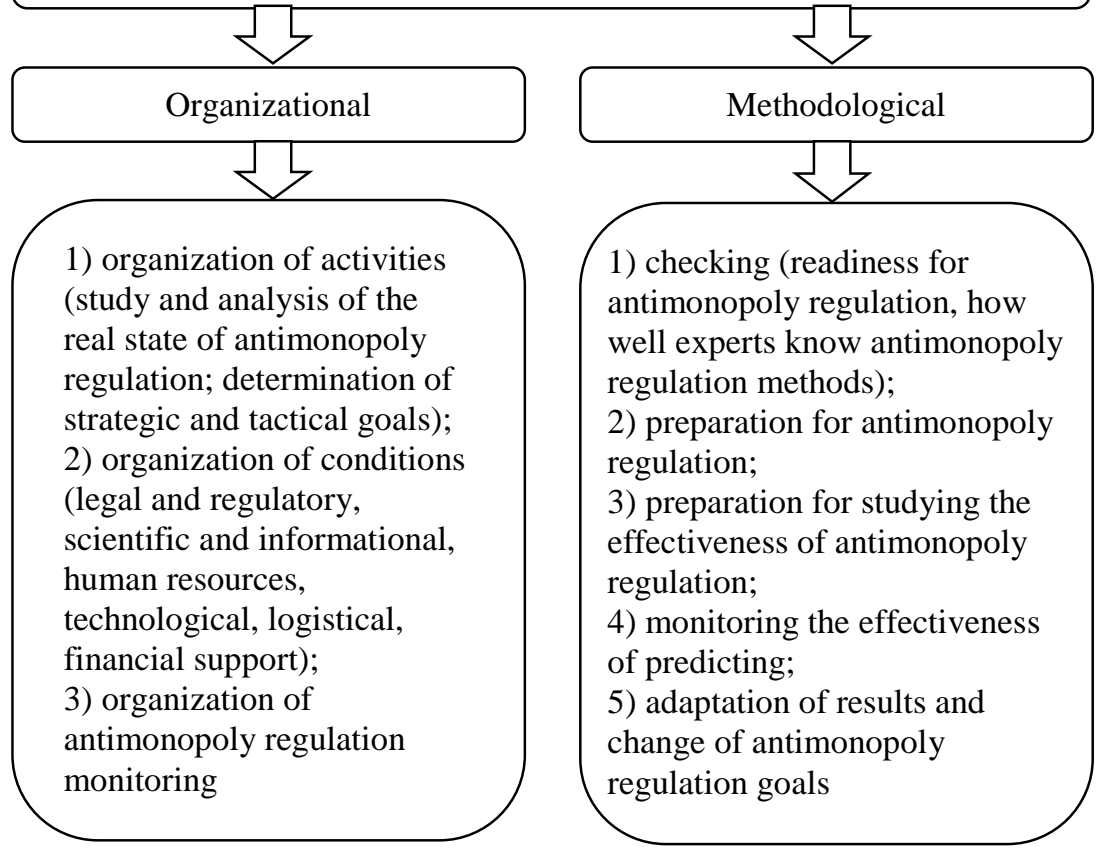

Figure 1. Components of Organizational and Methodological Principles of Predicting of the Economy Antimonopoly Regulation Under the Conditions of Terms of the Economy Digitalization.

Thus, when predicting the antimonopoly activities of the state it is necessary to take into account its organizational and methodological support and be informed about the competitive situation in national markets.

Structural background for competition in various sectors of the economy is formed by taking into account certain factors. In particular, the functioning features of each sector significantly influence them. The functioning features of each of the sectors determine the creation and operation of the appropriate market structure.

For a more detailed analysis of different markets and their functioning features, a cluster analysis of these sectors was conducted 
based on the economic performance of various sectors of the economy. Basic data for 2018 is presented in Table 2. According to the cluster analysis results, the economy sectors were divided into 5 clusters presented in Table 3. For convenience, the number was assigned to each of the sectors, according to their numbers in Table 3. This classification and dividing of different sectors of the economy into clusters were made analyzing the Tree Diagram obtained by using the Statistics analysis package. The Tree Diagram is shown in Figure 2.

Tree Diagram for 16 Cases Single Linkage

Euclidean distances

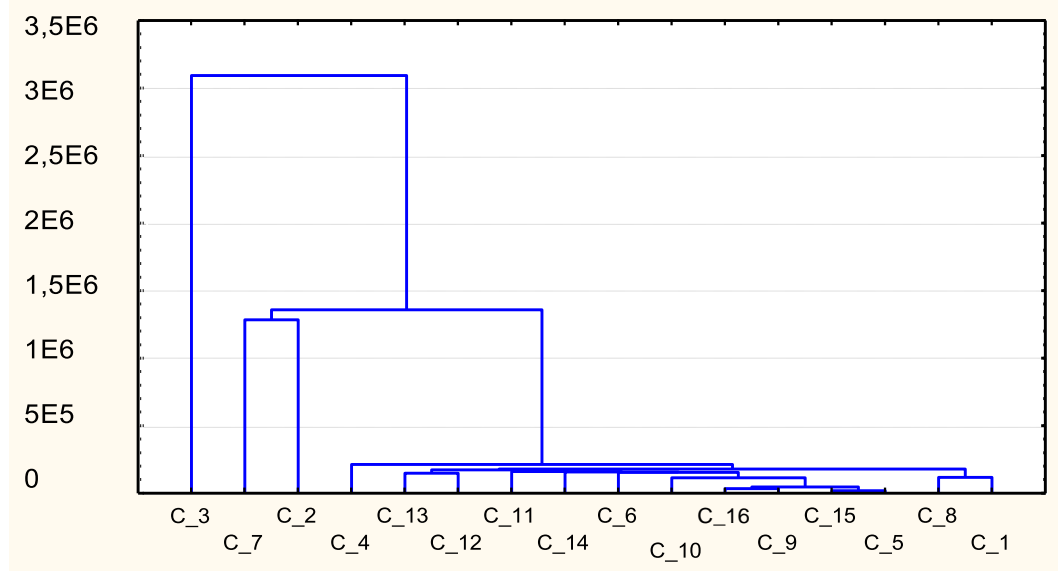

Figure 2. Diagram of the Cluster Analysis Results in 16 Sectors of the Economy.

The table shows that a large number of sectors are grouped into one cluster and, among all, there are sectors that are clearly different from all other sectors. Throughout the analyzed period, the sectors number 7, 3, 2 and 4, which correspond to "Wholesale and retail trade; auto and motorcycle repair (7)", "Processing industry (3)", "Mining and quarrying (2)" and "Electricity, gas, steam and conditioned air supply (4)" can be highlighted among other sectors. These sectors are significantly different from others, as evidenced by the significant differences between these and other sectors in the cluster analysis. 


\begin{tabular}{|c|c|c|c|c|c|c|c|c|c|}
\hline & 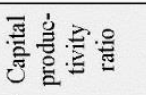 & $\underset{-}{F_{i}}$ & $\begin{array}{l}R \\
\stackrel{8}{n}\end{array}$ & $\stackrel{\mathbb{Z}}{-}$ & बे & $\stackrel{8}{-}$ & $\begin{array}{l}\overrightarrow{0} \\
n\end{array}$ & $\begin{array}{l}2 \\
\stackrel{2}{=}\end{array}$ & $\vec{m}$ \\
\hline & 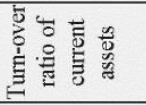 & $\stackrel{9}{\exists}$ & $\underset{f}{\Rightarrow}$ & $\cong$ & $\stackrel{\bar{n}}{\vec{N}}$ & $\sqrt{n}$ & Бू & $\begin{array}{l}\text { i } \\
\text { in }\end{array}$ & $\underset{\sim i}{ \pm}$ \\
\hline & 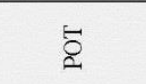 & 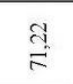 & 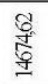 & $\begin{array}{l}\sqrt{n} \\
\infty \\
\infty \\
m\end{array}$ & 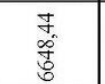 & $\begin{array}{l}\bar{\sigma} \\
\underset{f}{f}\end{array}$ & $\frac{n}{\tilde{8}}$ & $\begin{array}{l}\infty \\
\text { if } \\
\text { fr }\end{array}$ & ڤ్ \\
\hline & 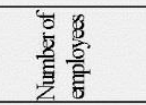 & 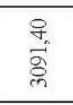 & $\begin{array}{l}\approx \\
\stackrel{\circ}{ }\end{array}$ & 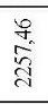 & $\begin{array}{l}3 \\
\text { in }\end{array}$ & $\begin{array}{l}\hat{8} \\
\text { m }\end{array}$ & 导 & 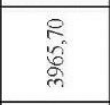 & $\stackrel{q}{\stackrel{q}{\prime}}$ \\
\hline & ह 륳 & $\begin{array}{l}8 \\
\text { है } \\
\text { है }\end{array}$ & శ్ & $\begin{array}{l}\frac{5}{7} \\
\frac{7}{8}\end{array}$ & $\begin{array}{l}\frac{8}{8} \\
\frac{5}{5}\end{array}$ & $\begin{array}{l}\frac{8}{8} \\
\frac{5}{8} \\
5\end{array}$ & $\begin{array}{l}8 \\
8 \\
8 \\
8 \\
8\end{array}$ & 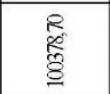 & ફ̊ \\
\hline & 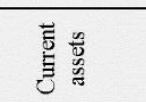 & 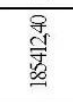 & $\begin{array}{l}\text { के } \\
\text { तु } \\
\text { है }\end{array}$ & 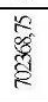 & $\begin{array}{l}\stackrel{\circ}{\circ} \\
\stackrel{h}{\varrho}\end{array}$ & $\begin{array}{l}\stackrel{\infty}{\circ} \\
\stackrel{2}{\varrho}\end{array}$ & $\begin{array}{l}8 \\
8 \\
8 \\
0\end{array}$ & है & 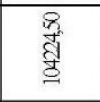 \\
\hline & 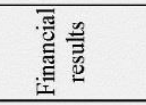 & $\begin{array}{l}\text { f } \\
\text { E⿱ } \\
\stackrel{1}{1} \\
\end{array}$ & $\begin{array}{l}\text { 옹 } \\
\text { ?ִ }\end{array}$ & 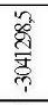 & 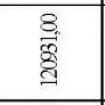 & $\begin{array}{l}R \\
\mathscr{6} \\
? \\
\end{array}$ & 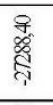 & 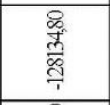 & $\begin{array}{l}8 \\
\S \\
5 \\
\end{array}$ \\
\hline & 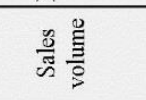 & 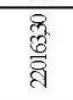 & $\begin{array}{l}8 \\
\stackrel{8}{*} \\
\text { ह } \\
2\end{array}$ & 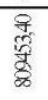 & $\begin{array}{l}8 \\
\text { 8 } \\
\text { ते } \\
\text { 1 }\end{array}$ & $\begin{array}{l}8 \\
8 \\
6 \\
6\end{array}$ & 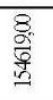 & 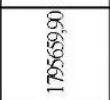 & 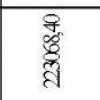 \\
\hline & 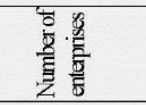 & \begin{tabular}{l}
8 \\
8 \\
8 \\
\hdashline \\
1
\end{tabular} & $\begin{array}{l}8 \\
8 \\
0 \\
0\end{array}$ & $\begin{array}{l}8 \\
\approx \\
\circ \\
\bar{్}\end{array}$ & $\begin{array}{l}8 \\
6 \\
i \\
\infty\end{array}$ & $\begin{array}{l}8 \\
5 \\
0\end{array}$ & $\begin{array}{l}8 \\
8 \\
\infty \\
\\
\end{array}$ & $\begin{array}{l}8 \\
\text { 过 } \\
8 \\
\&\end{array}$ & $\begin{array}{l}8 \\
\stackrel{8}{0} \\
ٍ \\
\end{array}$ \\
\hline & ิิ & 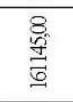 & $\begin{array}{l}8 \\
\frac{1}{2} \\
\frac{\pi}{2}\end{array}$ & $\begin{array}{l}8 \\
8 \\
\text { 害 }\end{array}$ & $\begin{array}{l}8 \\
8 \\
60 \\
0 \\
\text { g }\end{array}$ & $\begin{array}{l}8 \\
6 \\
0 \\
1\end{array}$ & $\begin{array}{l}8 \\
80 \\
\infty \\
0 \\
0\end{array}$ & है & $\begin{array}{l}8 . \\
8 \\
8 \\
8\end{array}$ \\
\hline & 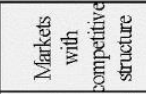 & $\begin{array}{l}\bar{\sigma} \\
\ddot{\alpha}\end{array}$ & 8 & $\frac{t}{\stackrel{7}{8}}$ & 8 & 8 & $\begin{array}{l}\text { ळ్ } \\
\text { ğ }\end{array}$ & $\begin{array}{l}\infty \\
\stackrel{0}{0} \\
8\end{array}$ & $\begin{array}{l}\delta \\
\Omega \\
\Omega\end{array}$ \\
\hline $\begin{array}{l}\circ \\
0 \\
5 \\
\frac{3}{3}\end{array}$ & 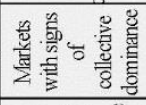 & $\stackrel{3}{-}$ & 告 & $\begin{array}{l}\text { वे } \\
\text { ते }\end{array}$ & 8 & 8 & $\begin{array}{l}8 \\
8 \\
\infty \\
-\end{array}$ & $\stackrel{\text { fro }}{\stackrel{2}{0}}$ & $\begin{array}{l}\infty \\
n^{\circ}\end{array}$ \\
\hline $\begin{array}{l}\bar{w} \\
\frac{0}{2} \\
\frac{y}{\tilde{n}} \\
\Sigma\end{array}$ & 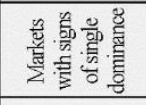 & if & $\begin{array}{l}\underset{J}{J} \\
\tilde{f}\end{array}$ & $\begin{array}{c}8 \\
\text { 仿 }\end{array}$ & $\begin{array}{l}1 \\
2 \\
8\end{array}$ & $\underset{\sim}{\mathbb{D}}$ & $\begin{array}{l}8 \\
\text { di }\end{array}$ & 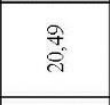 & $\begin{array}{l}\infty \\
\text { m } \\
\text { mे }^{2}\end{array}$ \\
\hline & 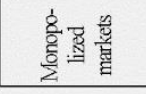 & ชู & ત્ & $\stackrel{3}{3}$ & 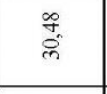 & $\frac{0}{8}$ & $\stackrel{\Xi}{\stackrel{\Xi}{\circ}}$ & $\begin{array}{l}\infty \\
\ddot{c} \\
\sim\end{array}$ & $\underset{\text { हn }}{E}$ \\
\hline & : & 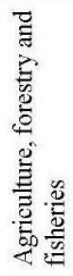 & 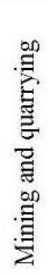 & 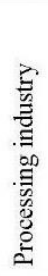 & 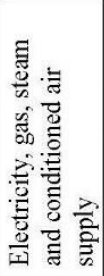 & 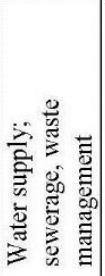 & 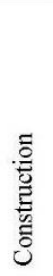 & 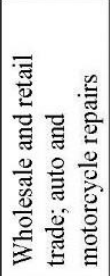 & 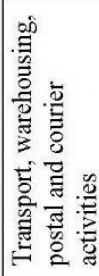 \\
\hline
\end{tabular}




\begin{tabular}{|c|c|c|c|c|c|c|c|c|}
\hline 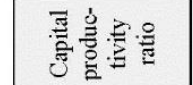 & 总 & $\underset{\infty}{\infty}$ & $\stackrel{\substack{0 \\
0}}{0}$ & 孚 & : & वे & $\stackrel{0}{\rightarrow-1}$ & 8 \\
\hline 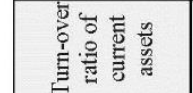 & â & $\stackrel{\vec{m}}{i}$ & है & 景 & $\begin{array}{l}: \\
:\end{array}$ & $\vec{\exists}$ & $\overrightarrow{3}$ & \\
\hline 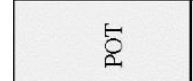 & ले & $\stackrel{\circ}{\Rightarrow}$ & $\begin{array}{l}8 \\
\stackrel{2}{8} \\
\text { gे }\end{array}$ & ले & 苟 & g. & : & \\
\hline 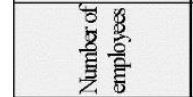 & 产 & 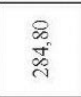 & 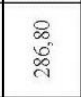 & 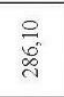 & 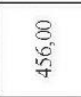 & 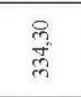 & $\begin{array}{l}\text { वे } \\
\text { तิ }\end{array}$ & \\
\hline 豆产 & 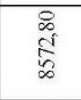 & 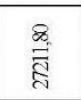 & \begin{tabular}{l}
8 \\
8 \\
8 \\
\hdashline
\end{tabular} & 疍 & $\begin{array}{l}8 \\
8 \\
\frac{8}{8}\end{array}$ & 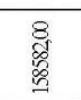 & $\begin{array}{l}\frac{8}{\alpha} \\
\stackrel{\sigma}{\Rightarrow}\end{array}$ & \\
\hline 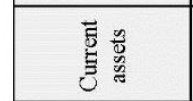 & 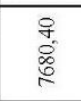 & 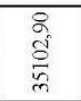 & 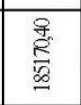 & 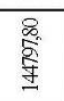 & 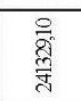 & 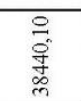 & 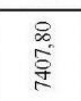 & \\
\hline 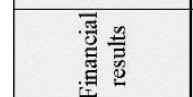 & $\begin{array}{l}8 \\
0 \\
0 \\
6 \\
6\end{array}$ & $\begin{array}{l}8 \\
6 \\
\frac{6}{1}\end{array}$ & $\begin{array}{l}8 \\
8 \\
8 \\
0.0 \\
0.0\end{array}$ & 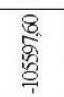 & $\begin{array}{l}\text { 产 } \\
\text { 多 }\end{array}$ & 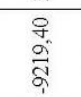 & 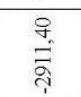 & \\
\hline 3 & $\begin{array}{l}8 \\
0.0 \\
\text { d. } \\
\text { di } \\
\end{array}$ & $\begin{array}{l}8 \\
\text { 落 } \\
\end{array}$ & \begin{tabular}{|l|}
8 \\
8 \\
0 \\
8 \\
8
\end{tabular} & 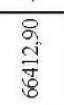 & 视 & 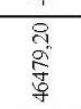 & 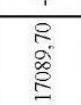 & \\
\hline 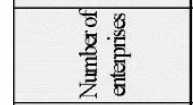 & $\begin{array}{l}8 \\
8 \\
0 \\
b \\
n \\
n\end{array}$ & $\begin{array}{l}8 \\
8 \\
\text { 量 } \\
\end{array}$ & \begin{tabular}{|l|}
8 \\
$\infty$ \\
$\infty$ \\
$\stackrel{0}{=}$ \\
\hdashline
\end{tabular} & $\begin{array}{l}8 \\
0 \\
0 \\
\vdots \\
5\end{array}$ & 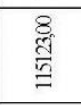 & $\begin{array}{l}8 \\
\text { 势 } \\
\text { 年 }\end{array}$ & 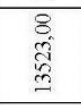 & \\
\hline डิ흐 & $\begin{array}{l}8 \\
\text { సू. } \\
\end{array}$ & 亲 & 8 & $\begin{array}{l}8 \\
\frac{8}{3} \\
\end{array}$ & $\begin{array}{l}8 \\
\text { 离 } \\
\end{array}$ & $\begin{array}{l}8 \\
8 \\
8 \\
\end{array}$ & 䓫 & \\
\hline 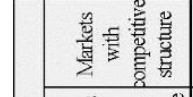 & $\begin{array}{c}\text { तो } \\
\text { gi } \\
\text { d }\end{array}$ & ले & $\stackrel{\infty}{\Rightarrow}$ & $\begin{array}{l}\text { J. } \\
\text { Oे } \\
\infty\end{array}$ & 18 & $\begin{array}{l}\hat{m} \\
\dot{\sigma} \\
\end{array}$ & $\stackrel{\infty}{\infty}$ & \\
\hline$\frac{2}{5}$ & : & $E$ & $\begin{array}{l}\infty \\
\vdots \\
\vdots\end{array}$ & ర్రి & $\begin{array}{c}8 \\
\text { in }\end{array}$ & $\stackrel{-}{9}$ & $\stackrel{\infty}{\rightarrow}$ & \\
\hline 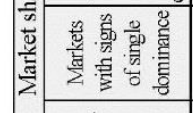 & 量 & $\frac{n}{8}$ & $\underset{\infty}{\infty}$ & $\stackrel{\infty}{\stackrel{\infty}{\infty}}$ & 志 & $\begin{array}{l}8 \\
\text { 学 }\end{array}$ & $\frac{\pi}{2}$ & \\
\hline 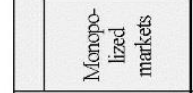 & $\frac{n}{6}$ & $\stackrel{\infty}{0}$ & $\stackrel{\circ}{\prime}$ & $\Xi_{0}$ & ] & $m$ & $\underset{\infty}{\infty}$ & \\
\hline 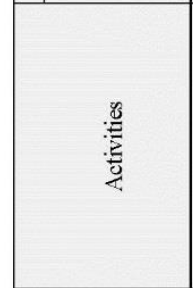 & 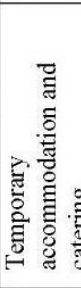 & 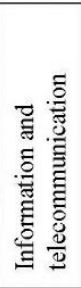 & 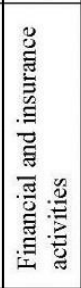 & 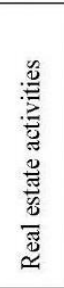 & 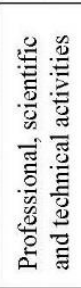 & 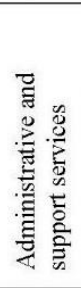 & 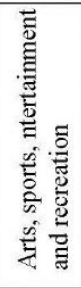 & \\
\hline
\end{tabular}




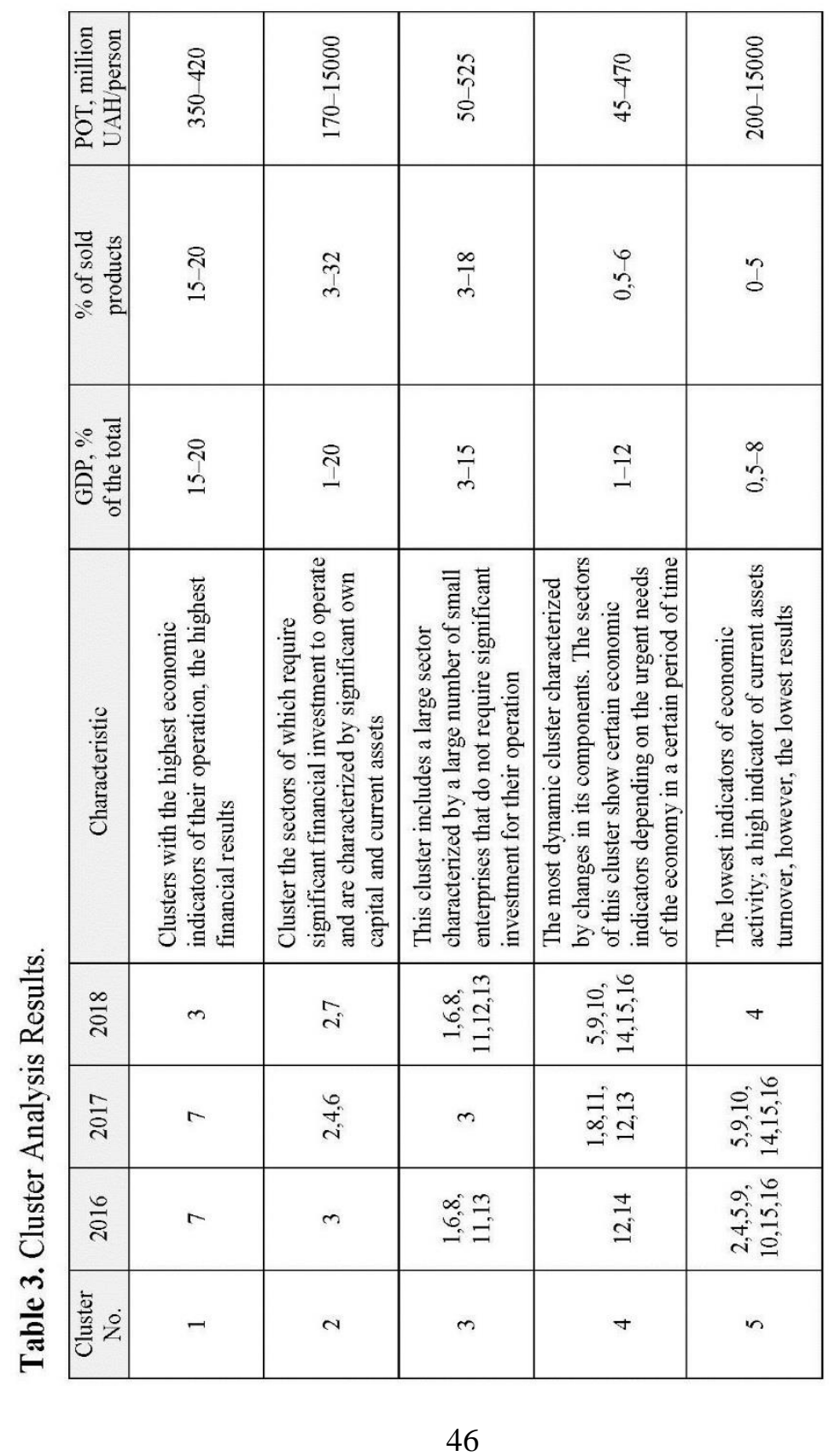


Cluster mergers are one of the ways to organize the innovation processes of all complexes, whereby several companies compete, and the cost of production is reduced as a result of joint technological cooperation. Merging into clusters creates a special economic space to improve the conditions for free trade, free movement of capital and human resources.

Clusters in the economy are a model of a competitive and investment-friendly economy, which is aimed at providing high living standards.

The clusters are needed because:

- innovation processes often require resources and competencies from the outside of a company;

- clusters are a combination of competition and cooperation;

- clusters are part of a broader concept of competitiveness;

- cluster associations or associations of local regional production systems contribute to the economic growth of regions.

The clustering method is used:

- for competitiveness analysis;

- to ensure socioeconomic development;

- to develop economic development strategies;

- to ensure innovation policy;

- as a basis for large and small business interaction.

The main purpose of clustering is to increase the domestic and international competitiveness of its members through commercial and noncommercial cooperation, research and innovation, education, training and support.

The positive features of cluster interaction are:

- increased efficiency of production;

- effective innovation policy;

- providing access to specialized suppliers, services, skilled labor, technological knowledge;

- greater flexibility and large-scale impact;

- common activity;

- collective efficiency.

The disadvantages of cluster interaction can be:

- physical infrastructure;

- lack of available capital;

- remoteness of regions; 
- insufficient number of skilled experts.

Thus, dividing economic sectors into clusters makes it possible to analyze separately the features of functioning of each of the sectors in more detail. The features of functioning definitely affect the general competitive situation of each of the markets. The resulting clusters allow us to understand the reasons of structural preconditions of functioning of competition in different markets, relying on economic indicators, results of activity of various sectors, having determined their features and key characteristics, including those that determine the choice of payment tools and prospects for the development of the mechanism of digital assets.

Further analysis should include an analysis of the structure of the markets, the type of markets, the general competitive situation in the market and the processes taking place in it. This will make it possible to understand the peculiarities of its development, the reasons for the functioning of its structure and type, as well as allow us to respond to its changes and regulate its activities as required.

The existing postulates and concepts of economic development of the country are changed as digital technologies develop. The previous method of production, building the economy in the industrial complex are a thing of the past, and information and digital assets come to the fore.

Scientists Nadzhafov and Huseinova agree with this statement and identify the following main aspects of economic development of the world in their work [61, p. 52]: digital, network, global, sustainable and innovative, emphasizing the latest trends in economic development in the XXI century.

The above-mentioned determines the emergence of new phenomena and processes, the formation of the conceptual and categorical apparatus of the information and digital sphere. For example, the process of digitization is considered in broad and narrow senses. In a narrow sense, scientists Yehorov I. and Ryzhkova Yu. [62, p. 9] understand digitization as a certain conversion of analog data and processes into digital ones, which makes data and operations with them much more productive than when using analog technologies.

In a broader sense, digitization is the use of data and digital technologies, as well as the relationship between them, which leads to new or changes in the existing activities, while digital transformation concerns the economic and social consequences of digitalization [62, p. 9]. 
Digital processes in the economies of the world generate a new concept in economics, namely the digital economy. According to Klenin O. [63, p. 44], digital economy means "a system of economic and sociocultural relations based on the use of digital information and communication technologies, the operation of which is aimed at increasing the efficiency of social production, maintaining sustainable economic growth to improve welfare and quality of life".

The author's vision of the structure and components of the digital economy are shown in Figure 3.

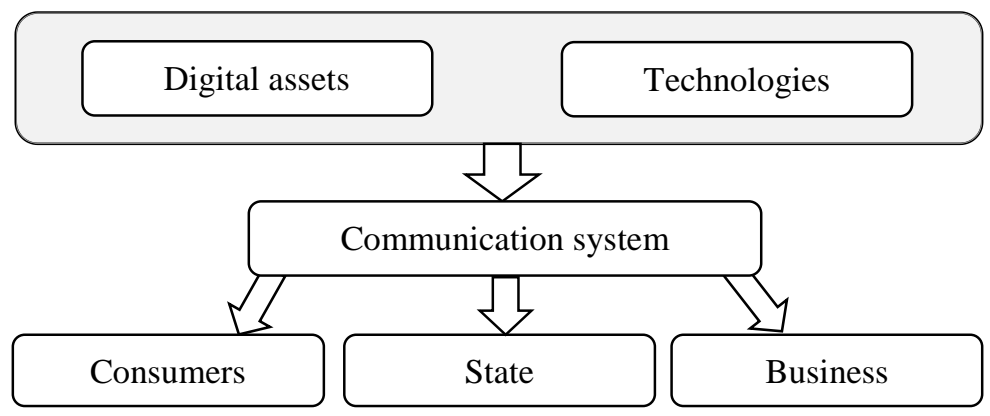

Figure 3. Components of the Digital Economy System.

Thus, we propose to understand the digital economy as a system of digital assets and technologies that interact with consumers, the state and business through the communication system to achieve the goals of sustainable development of the country.

The processes of digitalization and introduction of digital assets in various spheres of socioeconomic development of the country generate new phenomena in the economy and accelerate the existing ones. Those processes and methods that took much time in the process of implementing digital assets in the past are accelerated and automated.

Market competition and digitalization processes are studied using the Digital Economy and Society Index (DESI). Regular monitoring of the processes of digitalization of the EU economies allows us to track trends and predict the development of each individual country according to the relevant indicator. DESI includes the following indicators:

- Communication - development of the broadband communication market in the EU; 
- Human capital - digital inclusion and skills;

- Use of Internet services;

- Integration of digital technologies;

- Digital public services;

- EU ICT sector and its research;

- Research and innovation: ICT projects in the "Horizon 2020" digital program [64].

These indicators together constitute an index of the digital economy and society, which allows us to understand the competitiveness of EU countries in terms of digital development and the impact of digital assets on socioeconomic development (Figure 4).

\section{DESI 2019}

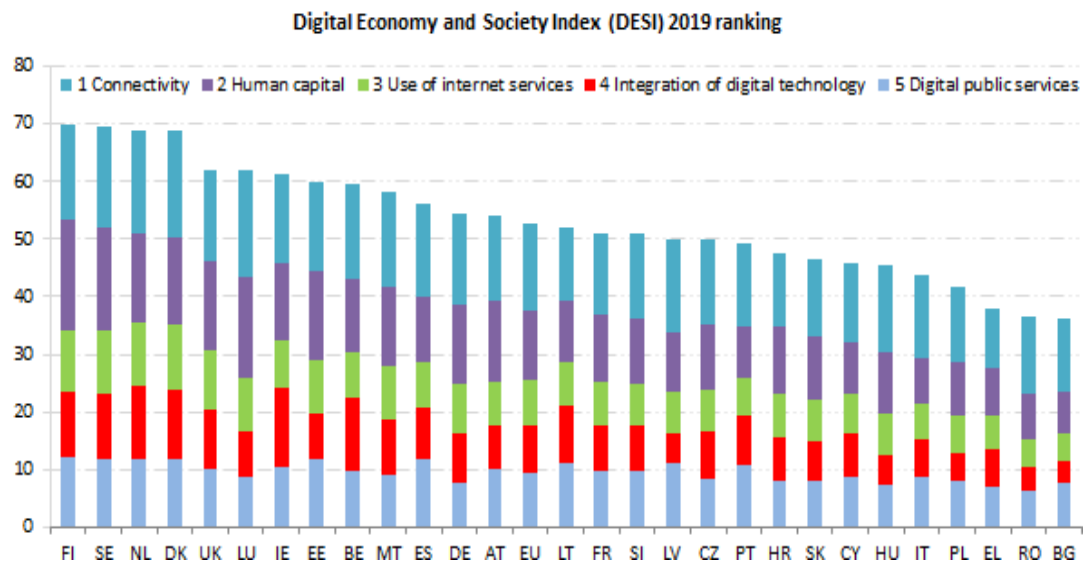

Figure 4. Digital Economy and Society Index Ranking [64].

The study of market structure, its type and economic processes is associated with determining the state of the competitive environment, its assessment and study of opportunities to restrict or develop competition while introducing new technologies for economic activity, in particular, related to digital assets and other information products, the introduction of which is associated with improving the efficiency of capital use in order to accelerate the funds flow and carry out non-cash payments, expand the range of sources of investment resources, etc. 
Thus, the reasons for restricting the use of cash are usually high expenditures on their turnover (expenditures on production, issue, organization of turnover, as well as expenditures associated with the destruction of old banknotes). Another influential factor is the anonymous nature of cash, which stimulates the growth of the shadow economy. Therefore, there is an assumption that the state should direct its regulatory instruments to the development and promotion of the use of non-cash payments in retail trade. At the same time, an increased share of non-cash payments provides a significant reduction in payment time, protection against theft, increased reliability and efficiency of payments, as well as accelerated circulation of funds, which will allow banks to use their customers' balances for lending and investing in the country's economy.

Today, cash (banknotes, coins), payment bank cards (credit, debit), checks, bank transfers, as well as electronic money, the nature of which is close to private money, are used as means of payment in retail transactions. Each means of payment has its own characteristics that allow it to occupy a certain position in the retail payment market. For easy analysis, it is proposed to refer all the studied means of exchange, including both means of payment (money) issued by the National Bank and liabilities of commercial banks and other institutions used to repay certain obligations or conduct purchase and sale transactions to the means of payment. First of all, it is necessary to identify the fundamental differences between the mentioned means of payment:

- cash is issued by the central bank in the form of banknotes and coins, and considered by all agents as a legal tender [65];

- deposit money is various mechanisms of access to a bank account.

Despite the fact that there are many such mechanisms, this analysis considers [66]:

- internet banking is a mechanism for personal current account management on the basis of interaction protocols defined by the bank and traditional clearing mechanisms used by banks or payment providers;

- bank cards (including virtual ones) are a mechanism for accessing special accounts opened by the bank using interaction and clearing protocols; developed and maintained by international and national payment systems;

- electronic money (e-money) is units of value stored on an 
electronic device, accepted as a means of payment by persons other than the person issuing them, and is a monetary obligation of this person performed in cash or non-cash form $[67 ; 68]$.

In turn, electronic money includes three groups of products:

- electronic wallets are rechargeable multi-purpose prepaid cards that store the electronic value used to make retail payments $[69, \mathrm{p}$. 376]. It is important to note that e-wallets are produced in closed circulating systems, the feature of which is that they do not allow multiple transfers of the same value between agents;

- network money is a prepaid product that allows you to use funds with special software. This software can be hosted both on the user's computer and on a remote server, and transactions take place via telecommunications networks (Internet, etc.);

- mobile money is a prepaid product that allows you to use funds through holding your phone close to a payment terminal; depositing and software update are carried out through a wireless channel.

In order to identify the competitive advantages of certain payment instruments, it is necessary to systematize the basic requirements (characteristics) imposed on the means of payment.

Specific factors that are important for issuing institutions, commercial banks, paying agents, sellers, the public and the state were taken into account during the analysis of these requirements. It is important to note that these instruments were considered only as a means of payment; their properties as a store of value were not considered.

Among the basic requirements are the following (Table 4).

Table 4. Basic Requirements to Means of Payment (Payment Instruments).

\begin{tabular}{|l|l|}
\hline Basic requirements & \multicolumn{1}{|c|}{ Characteristics } \\
\hline Ease of use & $\begin{array}{l}\text { They must be easy to use to ensure their mass } \\
\text { distribution and to avoid difficulties in their application. }\end{array}$ \\
\hline $\begin{array}{l}\text { Technological } \\
\text { effectiveness } \\
\text { of use }\end{array}$ & $\begin{array}{l}\text { Necessity is determined by the modern transformation } \\
\text { of the economy and the transition to a digital economy. }\end{array}$ \\
\hline Resistance to fraud & $\begin{array}{l}\text { Means of payment can be used by frauds if they are } \\
\text { insufficiently protected by the issuer, thus it is necessary } \\
\text { to develop mechanisms to protect means of payment. }\end{array}$ \\
\hline
\end{tabular}




\begin{tabular}{|c|c|}
\hline Basic requirements & Characteristics \\
\hline Anonymity & $\begin{array}{l}\text { An important requirement, as not all market participants } \\
\text { want to be identified in the course of business } \\
\text { transactions. }\end{array}$ \\
\hline Versatility & $\begin{array}{l}\text { Allows us to use means of payment in various economic } \\
\text { areas of circulation of financial instruments. Reducing } \\
\text { restrictions on the means of payment leads to its greater } \\
\text { spread. }\end{array}$ \\
\hline Reversibility & $\begin{array}{l}\text { The ability to be used as a means of payment between } \\
\text { any of the existing agents without special confirmation. }\end{array}$ \\
\hline $\begin{array}{l}\text { Providing } \\
\text { micro-payments }\end{array}$ & $\begin{array}{l}\text { The means of payment should be able to provide } \\
\text { payments with the accuracy provided by law. Thus, } \\
\text { economic expenses of agents for arranging such } \\
\text { payment should not deprive it of economic sense. }\end{array}$ \\
\hline Autonomy & $\begin{array}{l}\text { Availability of means of payment without connection to } \\
\text { a network. }\end{array}$ \\
\hline Portability & $\begin{array}{l}\text { It means that the means of payment at the present stage } \\
\text { are moving to other levels and have more different areas } \\
\text { of application and types [69]. }\end{array}$ \\
\hline Time of use & $\begin{array}{l}\text { The need for clearly defined time and conditions of use } \\
\text { of means of payment or timeless use. }\end{array}$ \\
\hline Liquidity & $\begin{array}{l}\text { It means problem-free exchange of means of payment } \\
\text { for cash. }\end{array}$ \\
\hline $\begin{array}{l}\text { Economically } \\
\text { rational cost } \\
\text { of servicing } \\
\text { operations } \\
\text { for ecosystem } \\
\text { participants }\end{array}$ & $\begin{array}{l}\text { It is a complex parameter that includes the following: } \\
\text { For the buyer: the cost of ownership of the payment } \\
\text { instrument and the amount of possible commissions for } \\
\text { conducting a payment transaction correspond to the size } \\
\text { of such transaction. } \\
\text { For the merchant: this indicator includes the cost of } \\
\text { transaction (commissions of payment systems and } \\
\text { financial agents or expenditures associated with the } \\
\text { processing of cash, etc.), as well as the cost of converting } \\
\text { the received means of payment into a form in which it } \\
\text { can be used in subsequent transactions (for example, } \\
\text { collection expenditures) correspond to the size of such } \\
\text { transactions. } \\
\text { For the bank: expenditures related to servicing and } \\
\text { processing of payment instruments [69]. }\end{array}$ \\
\hline $\begin{array}{l}\text { Additional } \\
\text { convenience }\end{array}$ & $\begin{array}{l}\text { Convenience of payments on the Internet. } \\
\text { Ability to plan, account and control personal expenses. }\end{array}$ \\
\hline
\end{tabular}




\begin{tabular}{|l|l|}
\hline Basic requirements & \multicolumn{1}{|c|}{ Characteristics } \\
\hline $\begin{array}{l}\text { Issuance } \\
\text { expenditures [9] }\end{array}$ & $\begin{array}{l}\text { The expenditures on manufacturing a means of payment } \\
\text { and expenditures associated with ensuring the } \\
\text { functioning of electronic means of payment. }\end{array}$ \\
\hline $\begin{array}{l}\text { Possibility } \\
\text { of issuance } \\
\text { income generation }\end{array}$ & $\begin{array}{l}\text { This does not mean commission income related to } \\
\text { payment transactions, but the ability to receive income } \\
\text { directly from the issuance (seigniorage) or from the use } \\
\text { of funds received as a deposit (prepayment). }\end{array}$ \\
\hline
\end{tabular}

Let us consider the most popular means of payment in terms of the basic requirements. Table 5 shows the advantages and disadvantages of the means of payment, which are currently used for retail payments.

Table 5. The Means of Payment and Trends of Their Development.

\begin{tabular}{|c|c|c|c|}
\hline Means & Advantages & Disadvantages & Trends \\
\hline Cash & $\begin{array}{l}\text { Free use, legal means } \\
\text { of payment; easy } \\
\text { payments (for small } \\
\text { amounts); accepted } \\
\text { everywhere; "peer-to- } \\
\text { peer" (P2P) } \\
\text { payments; anonymous } \\
\text { payments. }\end{array}$ & $\begin{array}{l}\text { Significant public } \\
\text { expenditures on cash } \\
\text { turnover; high risk of } \\
\text { loss as a result of } \\
\text { criminal acts and } \\
\text { natural disasters; } \\
\text { difficulties in large } \\
\text { payments; not suitable } \\
\text { for remote payments } \\
\text { on the Internet. }\end{array}$ & $\begin{array}{l}\text { Keep the niche } \\
\text { of small } \\
\text { payments; less } \\
\text { used for medium } \\
\text { and large } \\
\text { payments; } \\
\text { increasingly } \\
\text { more cash } \\
\text { transactions. }\end{array}$ \\
\hline $\begin{array}{l}\text { Debit } \\
\text { cards }\end{array}$ & $\begin{array}{l}\text { Easy use, especially } \\
\text { for medium } \\
\text { payments; low } \\
\text { transaction cost for } \\
\text { business; remote } \\
\text { payments; reduced } \\
\text { risk of losing all value } \\
\text { as the result of } \\
\text { criminal actions; } \\
\text { guaranteed payment } \\
\text { completion from the } \\
\text { issue bank and } \\
\text { payment system. }\end{array}$ & $\begin{array}{l}\text { Not a legal means of } \\
\text { payment; customers } \\
\text { need to pay for the } \\
\text { issuance and use of } \\
\text { their cards; need for } \\
\text { special infrastructure; } \\
\text { difficult P2P } \\
\text { payments; risks of } \\
\text { criminal actions in the } \\
\text { electronic } \\
\text { environment. }\end{array}$ & $\begin{array}{l}\text { Gradual increase } \\
\text { in the share of } \\
\text { the market } \\
\text { payments; } \\
\text { significant } \\
\text { increase in the } \\
\text { number of } \\
\text { transactions; } \\
\text { expanding } \\
\text { coverage as } \\
\text { infrastructure } \\
\text { develops. }\end{array}$ \\
\hline
\end{tabular}




\begin{tabular}{|c|c|c|c|}
\hline Means & Advantages & Disadvantages & Trends \\
\hline $\begin{array}{l}\text { Credit } \\
\text { cards [12] }\end{array}$ & $\begin{array}{l}\text { Easy use; credit the } \\
\text { option for the client; } \\
\text { incentives for } \\
\text { shopping; possibility } \\
\text { of remote payments; } \\
\text { reducing the risks of } \\
\text { losing value as the } \\
\text { result of criminal } \\
\text { actions. }\end{array}$ & $\begin{array}{l}\text { Not a legal means of } \\
\text { payment; high cost } \\
\text { per transaction; } \\
\text { customers need to pay } \\
\text { for the use of their } \\
\text { cards and know how } \\
\text { to use credit; the } \\
\text { complexity of P2P } \\
\text { payments; necessity } \\
\text { of special } \\
\text { infrastructure. }\end{array}$ & $\begin{array}{l}\text { Gradual growth } \\
\text { or stagnation } \\
\text { depending on the } \\
\text { saturation of } \\
\text { credit market } \\
\text { and development } \\
\text { of infrastructure; } \\
\text { expanding } \\
\text { coverage as } \\
\text { infrastructure } \\
\text { develops. }\end{array}$ \\
\hline $\begin{array}{l}\text { Prepaid } \\
\text { cards } \\
\text { (e-money) }\end{array}$ & $\begin{array}{l}\text { Easy use, including } \\
\text { for micropayments; } \\
\text { possibility of remote } \\
\text { payments; possibility } \\
\text { to make anonymous } \\
\text { payments; possibility } \\
\text { of P2P payments. }\end{array}$ & $\begin{array}{l}\text { Necessity of special } \\
\text { infrastructure; high } \\
\text { transaction cost; high } \\
\text { risk of loss as the } \\
\text { result of criminal acts } \\
\text { or natural disasters; } \\
\text { restrictions on } \\
\text { anonymous payments } \\
\text { to banks. }\end{array}$ & $\begin{array}{l}\text { Dynamic growth } \\
\text { and constant } \\
\text { increase in the } \\
\text { number of } \\
\text { transactions; the } \\
\text { use is restricted } \\
\text { to micro and } \\
\text { medium } \\
\text { payments. }\end{array}$ \\
\hline $\begin{array}{l}\text { Internet } \\
\text { banking } \\
\text { (money } \\
\text { transfers) }\end{array}$ & $\begin{array}{l}\text { Low risks; possibility } \\
\text { to pay large sums. }\end{array}$ & $\begin{array}{l}\text { Difficult payment } \\
\text { procedure; difficult } \\
\text { P2P payments; high } \\
\text { transaction cost [68]. }\end{array}$ & $\begin{array}{l}\text { Gradual further } \\
\text { decrease in use; } \\
\text { saving the niche } \\
\text { of large } \\
\text { payments. }\end{array}$ \\
\hline
\end{tabular}

Thus, cash remains the most convenient means of payment for the consumer owing to such key characteristics as free use, being accepted everywhere, anonymous payments, easy payments. That is why it remains the leading payment tool not only in Ukraine but also in many countries where the infrastructure of non-cash payments is more developed.

In addition, the results of the analysis help to explain why bank (payment) cards being a sufficiently technological method of payment will be able to compete with cash payments in the near future. The advantages such as convenience, security and economy of use lead to an increase in the use of this payment instrument both in the world as a whole and in Ukraine in particular. 
Furthermore, the analysis of the basic requirements for the means of payment allowed us to identify the main consumer factors of increase in the use of electronic money. The main factor in the spread of electronic money is the possibility to make anonymous payments (the main advantage of cash). Of course, the cost of electronic money services is much higher than that of other means of payment. At the same time, the consumer is ready to pay extra money for the opportunity to remain anonymous.

However, imbalances that arise in the financial market as a result of the introduction of new information technologies are a manifestation and consequence of the imbalance of necessity to maintain integrity, synchronization and systemic unity of the stages of financial resources circulation in competitive markets. To summarize the characteristics of interaction between different components of this process, the characteristics of mutual influence and dependence between the sets (between two lists) of canonical variables have been determined using the method of building canonical correlations.

These sets (lists) include such parameters of groups of determinants of introduction of the latest information technologies for use of digital assets in business practices (Figure 5).

The increase in the share of non-cash payments in the payment operations of countries is a global trend. However, further increase in noncash turnover in Ukraine should be based on encouraging all market participants, especially the final consumer.

Analysis of the means of payment and their consumer characteristics allowed us to highlight the advantages and disadvantages of each of them and contrast them with cash (as the most common means of payment), which in turn allowed us to identify competitive consumer characteristics of each means of payment.

Therefore, in order to further stimulate non-cash payments, current and future payment instruments should acquire the advantages of cash payment, namely anonymity, free use, versatility, easy use. 


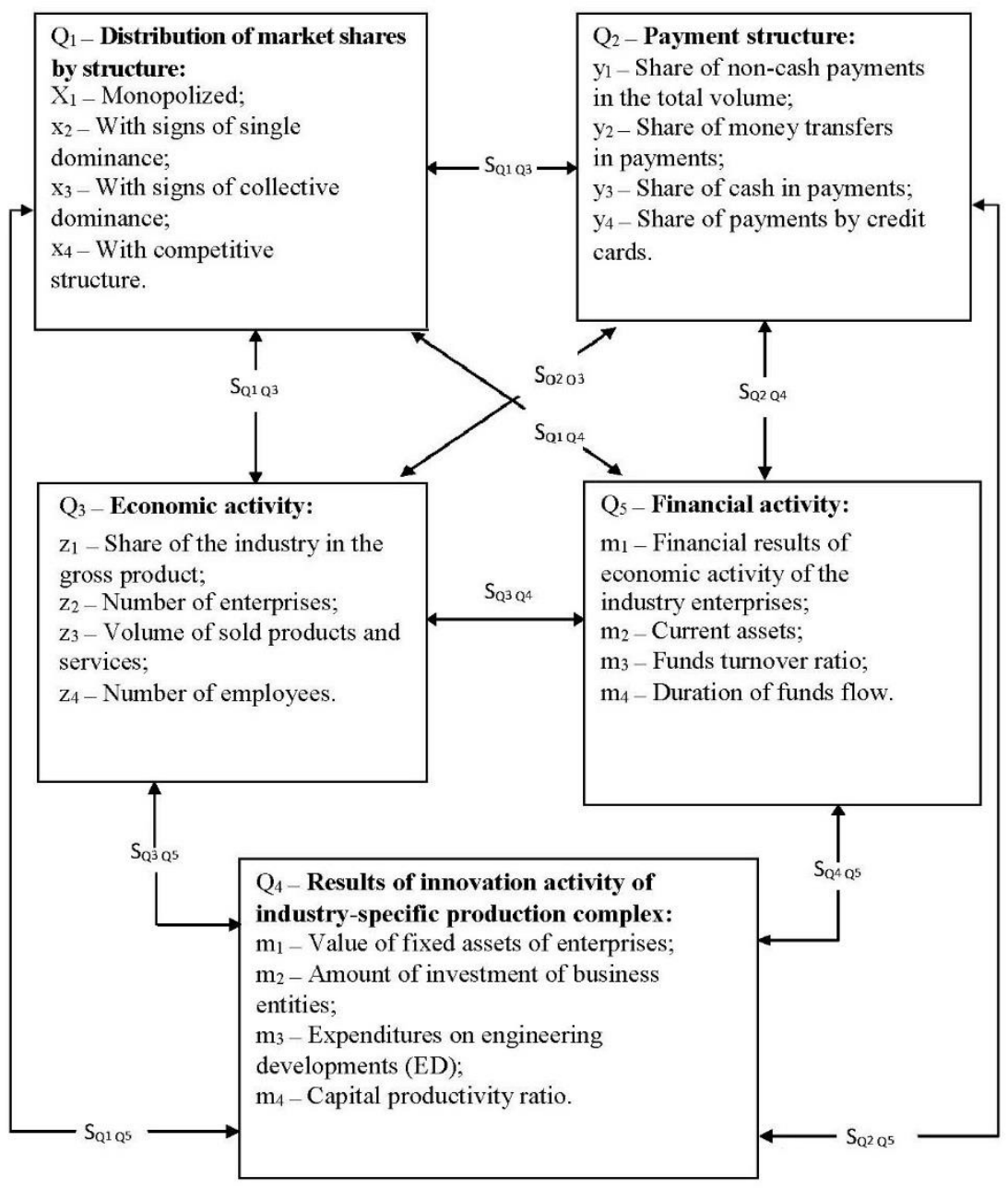

Figure 5. Groups of Determinants of Impact of the Competitive Parameters of Industry Markets on the Use of Financial and Information Non-Cash Payment Technologies. 
It should be noted that the introduction of digital assets requires an increase in public confidence in market participants and the infrastructure of non-cash payments in general. It should be also noted that the share of use of non-cash payments in total trading operations will depend on the state and development of the banking system, as well as the country's economy, devaluation and inflation expectations. Transferring savings to non-cash form with the banking system in its current state may increase the risks of their loss for people in the event of financial crises. In view of this, the system of administrative regulation and stimulation of non-cash payments at the national and global levels becomes an important area of further research. 


\section{CONCLUSIONS}

The phenomenon of socioeconomic development has been studied. The peculiarities of the sociocultural context, which form the understanding of the essence of socioeconomic development, have been substantiated.

The influence of modern information technologies, which significantly change the models and ways of doing business, has been determined.

The essence of the concept "digital asset" has been studied on the basis of etymological analysis.

The category "digital asset" has been introduced, which takes into account the essential and semantic features of the studied phenomenon and is characterized by four components: economic, legal, information, value. This allowed us to highlight the features of the use of this concept, as well as to clarify the relationship and dependence between its components.

The essence of predicting socioeconomic development from the influence of digital assets in the conditions of economy antimonopolization has been studied.

The principles of building economy antimonopoly regulation in the conditions of the economy digitalization have been determined. The components of organizational and methodological principles of predicting economy antimonopoly regulation under the conditions of economy digitalization have been determined, namely organization of activities (study and analysis of the real state of antimonopoly regulation; determination of strategic and tactical goals); organization of conditions (regulatory and legal, scientific and informational, human resoures, technological, logistical, financial support); organization of antimonopoly regulation monitoring; checking (readiness for antimonopoly regulation, how well experts know antimonopoly regulation methods); preparation for antimonopoly regulation; preparation for studying the effectiveness of antimonopoly regulation; monitoring the effectiveness of predicting; adaptation of results and change of antimonopoly regulation goals.

Sectors of the economy and features of their functioning have been analyzed with the help of cluster analysis, which will allow us to form a model of competitive and investment-friendly economy, which is aimed at providing a high living standards. 
It has been substantiated that imbalances which arise in the financial market as a result of the introduction of new information technologies are a manifestation and consequence of the imbalance of necessity to maintain integrity, synchronization and system unity of stages of financial resources circulation in competitive markets. To summarize the characteristics of interaction between different components of this process, the characteristics of mutual influence and dependence between the sets (between two lists) of canonical variables have been determined using the method of building canonical correlations. These sets (lists) include such parameters of groups of determinants of introduction of the latest information technologies for use of digital assets in business practices. 


\section{REFERENCES}

1. Департамент економічної стратегії та макроекономічного прогнозування. Економічний розвиток у розрізі регіонів України. Міністерство розвитку економіки, торгівлі та сільського господарства України: веб-сайт. URL: https://www.me.gov.ua (Last accessed: 14.01.2020).

2. The treaty on the functioning of the European Union. Official Journal of the European Union. 2012. Vol.55. URL: http://data.europa.eu/eli/treaty/tfeu_2012/oj

doi:10.3000/1977091X.C_2012.326.eng (Last accessed: 14.01.2020).

3. European Commission. Investment for jobs and growth. Promoting development and good governance in EU regions and cities. European Commission: website. URL: http://ec.europa.eu (Last accessed: 17.01.2020).

4. European Commission. Europe 2020. Priorities. European Commission: website. URL: http://ec.europa.eu (Last accessed: 18.01.2020).

5. Commission of the European Communities. Communication from the Commission to the Council and the European Parliament. European Environment Agency: website. URL: https://www.eea.europa.eu (Last accessed: 18.01.2020).

6. European Commission. Connecting Europe Facility. European Commission: website. URL: https://ec.europa.eu (Last accessed: 18.01.2020).

7. Atlantic Council and CEEP. Completing Europe - From the North-South Corridor to Energy, Transportation, and Telecommunications Union. Atlantic Council: website. URL: https://www.atlanticcouncil.org (Last accessed: 20.01.2020).

8. European Commission. Eurostat. European Commission: website. URL: http://ec.europa.eu (Last accessed: 20.01.2020).

9. Аверьянов М., Евтушенко С., Кочетова Е. Цифровая экономика: новые активы. itWeek: веб-сайт. URL: https://www.itweek.ru (дата обращения: 02.02.2020).

10.Арянова Т. Какое будущее ждет цифровые активы. Ihodl Russia: веб-сайт. URL: https://ru.ihodl.com (дата обращения: 02.02.2020). 
11.Сапожков О., Крючкова Е. Цифровые активы двинулись вспять. Коммерсантъ. 2018. №221. URL: https://www.kommersant.ru (дата обращения: 05.02.2020).

12.Buntinx J. P. Digital assets vs cryptocurrencies. The Merkle: website. URL: https://themerkle.com (Last accessed: 06.02.2020).

13.Fiduciary Access to Digital Assets and Digital Accounts: Act of 12.08.2014 // Delaware Code Online. URL: http://delcode.delaware.gov/title12/c050/index.shtml (Last accessed: 06.02.2020).

14.Gray G. H. New York's Fiduciary Access to Digital Assets Act. Gfrllp: web portal. Last updated: 20.10.2016. URL: http://gfrllp.com/Portals/gfrllp/Documents/NYS-Fiduciary-Access-toDigital-Assets-Gray-Feldman-LLP.pdf (Last accessed: 06.02.2020).

15.Harbinja E. Legal aspects of transmission of digital assets on death: Doctoral dissertation, University of Strathclyde. Glasgow, 2017. URL: http://digitool.lib.strath.ac.uk/R/?func=dbin-jumpfull\&object_id=28644 (Last accessed: 07.02.2020).

16.Kud A., Pypenko I. Social and economic foundation of the implementation of blockchain-based systems of digital assets in developing countries. International Journal of Education and Science. 2018. Vol. 1. No. 3-4. P. 30. doi:10.26697/ijes.2018.3-4.30

17.Have you made a plan for your digital assets? Osterman Law Firm: website. URL: https://www.ostermanlaw.com (Last accessed: 07.02.2020).

18. Walker M. D. The new uniform digital assets law: estate planning and administration in the information age. Real Property, Trust and Estate Law Journal. 2017. № 52 (1). P. 52-78. URL: https://www.americanbar.org/content/dam/aba/publications/real_propert y_trust_and_estate_law_journal/v52/01/rpte-journal-2017-52-1-articlenew-uniform-digital-assets-law-estate-planning-and-administration-ininformation-age\%20.authcheckdam.pdf (Last accessed: 10.02.2020).

19.Эфириум новости. В чем причина краха ETH? BitStat: вебсайт. URL: http://bitstat.top (дата обращения: 10.02.2020).

20.Захарова Н. Глава Ripple: “Криптовалюты - это не валюты, а цифровые активы”. BitGit: веб-сайт. URL: https://bitgid.com (дата обращения: 11.02.2020). 
21.Цегоев В. История одной монеты: как биткоин повлиял на мировой финансовый рынок за десять лет своего существования. $R T$ на русском: веб-сайт. URL: https://russian.rt.com (дата обращения: 12.02.2020).

22.Великая Е. Обложат ли виртуальные активы реальными налогами? Delo: веб-портал. Дата обновления: 07.12.2018. URL: https://delo.ua/econonomyandpoliticsinukraine/oblozhat-li-virtualnyeaktivy-realnymi-nalogami-348461 (дата обращения: 12.02.2020).

23.Про внесення змін до Податкового кодексу України щодо оподаткування операцій з віртуальними активами в Україні: проект Закону від 27.09.2018 № 9083-1 // Інформ.-правова система “ЛігаЗакон"/ВР України.

URL: http://search.ligazakon.ua/__doc2.nsf/link1/JH70B1AA.html (дата звернення: 15.02.2020).

24.Lenz D. M. Afterlife on the cloud: creating a heavenly plan for electronic assets. Bar Journal. 2012. URL: https://www.sssblaw.com/media/1104/afterlife_on_the_cloud.pdf (Last accessed: 15.02.2020).

25.Owens J. Blockchain 101 for Governments. Vienna: Wilton Park. URL: https://www.wiltonpark.org.uk/wpcontent/uploads/WP1566-Blockchain-101-for-Governments.pdf (Last accessed: 15.02.2020).

26.Latham \& Watkins discusses SEC official's analysis of digital assets as securities/Wink S. P. and others. The CLS Blue Sky Blog: web portal. Last updated: 02.07.2018. URL: http://clsbluesky.law.columbia.edu/2018/07/02/latham-watkinsdiscusses-sec-officials-analysis-of-digital-assets-as-securities/\#_edn4 (Last accessed: 15.02.2020).

27.ДСТУ 3966-2000. Термінологія. Засади і правила розроблення стандартів на терміни та визначення понять. [Чинний від 01.01.2001]. Київ: Держстандарт України, 2000. 36 с.

28.Научно-технический энциклопедический словарь. Академик: веб-сайт. URL: https://dic.academic.ru (дата обращения: 16.02.2020).

29.Ефремова Т. Ф. Новый словарь русского языка. 2-е изд. Москва: Русский язык, 2001. 1084 с. 
30.Финансы. Толковый словарь/общ. ред. И. М. Осадчая. 2-е изд. Москва: “Инфра-М”, издательство “Весь Мир”, 2000.

31.Энциклопедический словарь: в 86 т./под ред. И. Е. Андреевского и др. URL: www.vehi.net/brokgauz/ (дата обращения: 16.02.2020).

32.Райзберг Б. А., Лозовский Л. Ш., Стародубцева Е. Б. Современный экономический словарь. 6-е изд., перераб. и доп. Москва: Инфра-М, 2011. 512 с.

33.Ожегов С. И. Толковый словарь русского языка. Москва: Оникс: Biblio, 2010. $736 \mathrm{c}$.

34.Великий тлумачний словник сучасної української мови (3 дод. і допов.)/уклад. і голов. ред. В. Т. Бусел. Київ; Ірпінь: ВТФ "Перун", 2005. 1728 c.

35.Краткий словарь по кибернетике. Chernykh: веб-сайт. URL: http://chernykh.net (дата обращения: 16.02.2020).

36.Про затвердження Порядку подання та обігу електронних документів державному реєстратору юридичних осіб та фізичних осіб-підприємців: Наказ від 09.02.2016 № 359/5 // База даних “Законодавство України”/M-во юстиції України. URL: https://zakon.rada.gov.ua/laws/show/z0200-16 (дата звернення: 17.02.2020).

37.Про затвердження Порядку проведення електронних аукціонів з розподілення пропускної спроможності міждержавних електричних мереж: Постанова від 28.03.2017 № 426 // База даних “Законодавство України”/Нац. Коміс. України. URL: https://zakon.rada.gov.ua/laws/show/v0426874-17/ed20170328\#n63 (дата звернення: 17.02.2020).

38.Толковый словарь русского языка: в 4 т./под ред. Д. Н. Ушакова. Москва: Терра-Книжный клуб, 2007. Т. 4. 752 с.

39.Додонов В. Н., Ермаков В. Д., Крылова М. А. Большой юридический словарь. Москва: Инфра-М, 2009. 864 с.

40.Матузов Н. И., Малько А. В. Теория государства и права: учебн. 4-е изд., испр. и доп. Москва: Издательский дом “Дело” РаНХиГС, 2015. $528 \mathrm{c}$. 
41.Про Національну програму інформатизації: Закон від 01.09.2016 № 74/98-ВР // База даних “Законодавство України”/ВР України. $\quad U R L: \quad$ https://zakon.rada.gov.ua/cgibin/laws/main.cgi?nreg=74\%2F98-\%E2\%F0 (дата звернення: 17.02.2020).

42.Об информации, информатизации и защите информации: Закон Республики Беларусь от 10.11.2008 № 455-3 // База данных “Белтим СБ”. URL: https://www.beltim.by/wiki/documents/zakonrespubliki-belarus-ob-informatsii-informatizatsii/ (дата обращения: 17.02.2020).

43.Енциклопедія сучасної України: у 20 т. URL: http://esu.com.ua/search_articles.php?id=12472 (дата звернення: 18.02.2020).

44.Долинко В. И. Все об информационно-коммуникационных технологиях и системах связи: учебн. пособ. Москва: Litres, 2018. $59 \mathrm{c}$.

45.Финансовый словарь. Академик: веб-сайт. URL: https://dic.academic.ru/dic.nsf/fin_enc/23466 (дата обращения: 18.02.2020).

46.Поляков В. П., Косарев В. П. Информатика для экономистов: учебн. Москва: Издательство Юрайт, 2014. 524 с.

47.Шуремов Е. Л. Информационные ресурсы: классификация, источники, поставщики. Коротко о главном. Москва: Издательские решения, 2017. 150 с.

48.Прокопенко А. Н. О содержании понятия информационные ресурсы в праве. Бизнес в законе. 2010. № 1 . C. $157-160$.

49.Информационные ресурсы развития Российской Федерации: Правовые проблемы/отв. ред. И. Л. Бачило. Москва: Наука, 2003. 402 с.

50.Финансово-инвестиционный толковый словарь. Академик: веб-сайт. URL: https://dic.academic.ru (дата обращения: 18.02.2020).

51.Финансовый словарь. Академик: веб-сайт. URL: https://dic.academic.ru/dic.nsf/fin_enc/26068 (дата обращения: 18.02.2020). 
52.Уолпорт М. Технология распределенного реестра: за рамками блокчейн. Plus: веб-сайт. URL: https://www.plusworld.ru (дата обращения: 19.02.2020).

53.Применение технологии распределенного реестра для построения защищенного документооборота/Заворина Л. Д. и др. Известия Тульского государственного университета. 2018. Вып. 10. С. 3-7.

54.Савельев А. Юридическая дефиниция блокчейна. Zakon: веб-портал. Дата обновления: 30.10.2017. URL: https://zakon.ru/blog/2017/10/30/chast_2_yuridicheskaya_definiciya_bl okchejna_a_tochnee_-_raspredelennogo_reestra_dannyh (дата обращения: 19.02.2020).

55.Бизнес. Толковый словарь/общ. ред. И. М. Осадчая. Москва: “Инфра-М”, издательство “Весь Мир”, 1998.

56.Энциклопедический словарь. Tolkslovar: веб-сайт. URL: http://tolkslovar.ru (дата обращения: 19.02.2020).

57.Грабовецький Б. С. Планування та економічне прогнозування : навчальний посібник. Вінниця : ВНТУ, 2013. 66 с.

58.Стельмащук А. М. Державне регулювання економіки. Тернопіль: ТАНГ, 2000. 315 с.

59.Швайка Л. А. Державне регулювання економіки. Київ: Знання, 2006. 435 с.

60.Дикань Н. В., Борисенко I. I. Менеджмент: навч. посіб. для студентів, аспірантів, викладачів ВНЗ. Київ, 2008. 389 с.

61.Наджафов 3., Гусейнова А. Новая экономика XXI века или цифровизация экономики? Побудова інформаційного суспільства: ресурси $і$ технологї: матеріали XVIII Міжнародної наук.-практ. конф., 19-20 верес. 2019 р. Київ: УкрIНTЕI, 2019. С. 52-59.

62.Єгоров I., Рижкова Ю. Соціально-економічні аспекти процесів цифровізації: інструменти дослідження у країнах ОЕСР. Побудова інформаційного суспільства: ресурси $i$ технологї: матеріали XVIII Міжнародної наук.-практ. конф., 19-20 верес. 2019 р. Київ: УкрIНТЕI, 2019. С. 9-12.

63.Кленін О.В.основні тренди цифрової трансформації держави та бізнесу. Побудова інформаційного суспільства: ресурси i технології: матеріали XVIII Міжнародної наук.-практ. конф., 19-20 верес. 2019 р. Київ: УкрIНTЕI, 2019. С. 44-47. 
64.The digital economy and society index (DESI). European Commission: website. URL: https://ec.europa.eu (Last accessed: 15.02.2020).

65.World payments report 2014: Report of Capgemini and The Royal Bank of Scotland. Capgemini: website. URL: https://www.capgemini.com (Last accessed: 15.02.2020).

66.Ринок карткових платежів України: міжнародний досвід та національне регулювання. Аналітичний звіт. Київ: АДЕФ-Україна, 2012. $60 \mathrm{c}$.

67.Бублик Є. О. Обмеження готівкових розрахунків в Україні: проблеми та перспективи. Економіка і прогнозування. 2013. № 2. C. 32-42.

68.Лист 02/03-2014 НБУ від 15.04.2014 [додаток 1]: Українська міжбанківська асоціація членів платіжних систем. 2014. URL:

http://ema.com.ua/wpcontent/uploads/2014/05/strategy_development_ improvement_payments.pdf (дата звернення: 17.02.2020).

69.Кочергин Д. А. Электронные деньги. Санкт-Петербург: Маркет ДС, 2011. 424 c.

70.Ткачук А. В. Перспективы распространения безналичных розничных платежем. Деньги и кредит. 2012. № 7. С. 24-32.

71.Річний звіт Національного банку України за 2013 рік: затв. рішенням Ради Національного Банку України від 24.04.2014 p. № 13. URL: http://www.bank.gov.ua/doccatalog/document?id=8253030 (дата звернення: 17.02.2020). 


\section{Прогнозування вПливу цифрових активів на соціально-економічний розвиток підприємства Методичний посібник \\ (Англ. мовою)}

\section{КУДЬ Александр Александрович \\ МАЩЕНКО Марина Анатоліївна ПИПЕНКО Ірина Сергї̈вна СОБОЛЕВА Ірина Володимирівна \\ ISBN 978-617-7089-11-6 \\ DOI 10.26697/9786177089116.2020}

Видається в авторській редакції

Відповідальний випусковий: Ю. Б. Мельник

Комп'ютерне складання та верстання: Я. Ю. Свячена

Формат 80х64 $\frac{1}{6}$

Гарн. «Times». Папір для мн. ап. Друк цифровий.

Ум. друк. арк. 4,0. Зам. № 1-29.

Тираж 300 пр.

Харківський національний економічний університет імені С. Кузнеця Україна, 61166, м. Харків, пр. Науки, 9-а

Харківська обласна громадська організація “Культура Здоров'я"

Україна, 61105, м. Харків, пров. Забайкальський, 6/6. http://publisher.culturehealth.org; тел./факс: (057)775-75-23.

Emails: CultureHealth@ukr.net; KOSOCH@gmail.com;

Свідоцтво про державну реєстрацію видавництва ДК № 4387 від 10.08.2012 